\title{
Aerosol optical properties relevant to regional remote sensing of CCN activity and links to their organic mass fraction: airborne observations over Central Mexico and the US West Coast during MILAGRO/INTEX-B
}

\author{
Y. Shinozuka ${ }^{1, *}$, A. D. Clarke ${ }^{1}$, P. F. DeCarlo ${ }^{2,3, * *}$, J. L. Jimenez ${ }^{2,4}$, E. J. Dunlea ${ }^{2}$, G. C. Roberts ${ }^{5}$, J. M. Tomlinson ${ }^{6, * * *}$, \\ D. R. Collins ${ }^{6}$, S. G. Howell ${ }^{1}$, V. N. Kapustin ${ }^{1}$, C. S. McNaughton ${ }^{1}$, and J. Zhou ${ }^{1}$ \\ ${ }^{1}$ School of Ocean and Earth Science and Technology, University of Hawaii, Honolulu, HI, USA \\ ${ }^{2}$ Cooperative Institute for Research in the Environmental Sciences, University of Colorado, Boulder, CO, USA \\ ${ }^{3}$ Dept. of Atmospheric and Oceanic Sciences, University of Colorado, Boulder, CO, USA \\ ${ }^{4}$ Dept. of Chemistry and Biochemistry, University of Colorado, Boulder, CO, USA \\ ${ }^{5}$ Center for Atmospheric Sciences, Scripps Institution of Oceanography, La Jolla, CA, USA \\ ${ }^{6}$ Department of Atmospheric Sciences, Texas A\&M University, College Station, TX, USA \\ *now at: NASA Postdoctoral Program, NASA Ames Research Center, MS 245-5, Moffett Field, CA, USA \\ *** now at: Paul Scherrer Institut, 5232 Villigen-PSI, Switzerland \\ ${ }^{* * *}$ now at: Pacific Northwest National Laboratory, Richland, WA, USA
}

Received: 11 April 2009 - Published in Atmos. Chem. Phys. Discuss.: 26 May 2009

Revised: 20 August 2009 - Accepted: 29 August 2009 - Published: 17 September 2009

\begin{abstract}
Remote sensing of cloud condensation nuclei $(\mathrm{CCN})$ would help evaluate the indirect effects of tropospheric aerosols on clouds and climate. To assess its feasibility, we examined relationships of submicron aerosol composition to CCN activity and optical properties observed during the MILAGRO/INTEX-B aircraft campaigns. An indicator of CCN activity, $\kappa$, was calculated from hygroscopicity measured under saturation. $\kappa$ for dry $100 \mathrm{~nm}$ particles decreased with increasing organic fraction of non-refractory mass of submicron particles (OMF) as $0.34-0.20 \times \mathrm{OMF}$ over Central Mexico and 0.47-0.43 $\times$ OMF over the US West Coast. These fits represent the critical dry diameter, centered near $100 \mathrm{~nm}$ for $0.2 \%$ supersaturation but varied as $\kappa^{(-1 / 3)}$, within measurement uncertainty $(\sim 20 \%)$. The decreasing trends of $\mathrm{CCN}$ activity with the organic content, evident also in our direct $\mathrm{CCN}$ counts, were consistent with previous ground and laboratory observations of highly organic particles. The wider range of OMF, $0-0.8$, for our research areas means that aerosol composition will be more critical for estimation of CCN concentration than at the fixed sites previously studied. Furthermore, the wavelength dependence of extinction was anti-correlated with $\mathrm{OMF}$ as $-0.70 \times \mathrm{OMF}+2.0$ for
\end{abstract}

Correspondence to: Y. Shinozuka

(yohei@hawaii.edu)
Central Mexico's urban and industrial pollution air masses, for unclear reasons. The Angstrom exponent of absorption increased with OMF, more rapidly under higher single scattering albedo, as expected for the interplay between soot and colored weak absorbers (some organic species and dust). Because remote sensing products currently use the wavelength dependence of extinction albeit in the column integral form and may potentially include that of absorption, these regional spectral dependencies are expected to facilitate retrievals of aerosol bulk chemical composition and $\mathrm{CCN}$ activity over Central Mexico.

\section{Introduction}

Clouds act on the Earth's energy balance by reflecting incoming visible radiation and trapping the outgoing thermal infrared. It is well established that the aerosols that serve as cloud condensation nuclei $(\mathrm{CCN})$ affect cloud properties such as reflectivity, coverage, precipitation efficiency and lifetime (Twomey, 1974; Albrecht, 1989). To assess these so-called aerosol indirect effects, more complete knowledge of the $\mathrm{CCN}$ in the atmosphere for common cloud fields is crucial.

Published by Copernicus Publications on behalf of the European Geosciences Union. 


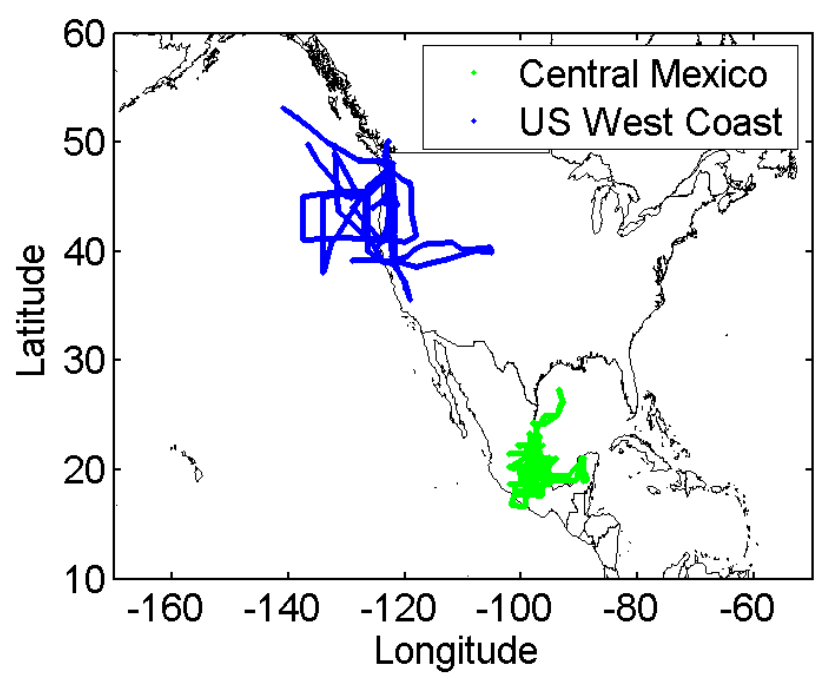

Fig. 1. Flight tracks of the C130 aircraft around Central Mexico (green) and the US West Coast (blue).

Ambient measurements of $\mathrm{CCN}$ in this context are sparse (Wang et al., 2008; Sorooshian et al., 2008; Kuwata et al., 2008; Bougiatioti, et al., 2009; Rose et al., 2008b). Their relatively short residence time in the troposphere, ranging from days to weeks, makes their concentration too variable over time and too inhomogeneous over space to adequately characterize from aircraft, ship or ground. In this regard, satellites, with their extensive and frequent coverage, would be a preferred observation platform (Garland et al., 2008; Andreae, 2009; Kinne, 2009).

Because aerosol chemical composition influences $\mathrm{CCN}$ activation it can impact the satellite remote sensing of $\mathrm{CCN}$ concentration. According to the Kohler equation the critical dry diameter - the minimum diameter of aerosols that can serve as $\mathrm{CCN}$ - is determined by the solubility and surface tension of the particles, at a given supersaturation and temperature. These chemical-composition-dependent parameters are poorly constrained for most aerosol components, particularly for the various types of organic compounds (Shulman et al., 1996; Facchini et al., 1999; Nenes et al., 2002; Raymond and Pandis, 2002; Kanakidou et al., 2005; Hartz et al., 2006; Ervens et al., 2007; Stroud et al., 2007; Cubison et al., 2008). Thus, even if the size distribution of aerosols were accurately retrieved and mixing state well understood, the uncertainty in the threshold diameter would hamper estimation of $\mathrm{CCN}$ concentration.

In this paper we approximate relationships between aerosol chemical composition and CCN activity over the Central Mexico and the United States (US) West Coast (Sect. 3), and present potential remote-sensing methods to infer the aerosol bulk chemical composition over Central Mexico (Sect. 4). We use aerosol size distribution, chemical composition, hygroscopicity, $\mathrm{CCN}$ number and optical properties measured in situ from aircraft over the two regions (Sect. 2).

\section{Experiments and instruments}

\subsection{Experiments}

The Megacities Impact on Regional and Global Environment (MIRAGE) Experiment took place in March 2006 as a part of the Megacity Initiative: Local and Global Research Observations (MILAGRO) Campaign (Molina et al., 2009; DeCarlo et al., 2008). The National Center for Atmospheric Research C130 aircraft was employed to sample the aerosols and gases above Central Mexico (Fig. 1). Most measurements were made between 3-5 km GPS altitude in local afternoon.

During the second part (17 April-15 May) of the Intercontinental Chemical Transport Experiment - Phase B (INTEXB) (Singh et al., 2009), the C130 flew over the US West Coast (Fig. 1) with the same instruments as those employed during MILAGRO. Atmospheric constituents arising from anthropogenic and biogenic emissions from the local areas (e.g. Seattle, Central Valley of California) and long-range transport from Asia were sampled. Most measurements were made below $6 \mathrm{~km}$ GPS altitude in local late morning and afternoon.

\subsection{Instrumentation}

Aerosols were collected and conveyed under near-ambient pressure to most of the aerosol instrumentation aboard the C130 aircraft through the University of Hawaii solid diffuser inlet. This inlet and sample plumbing has recently been shown to transmit dust and sea-salt particles with dry aerodynamic diameter of $5.0 \mu \mathrm{m}$ with a better than $50 \%$ efficiency during the DC-8 Inlet/Instrument Characterization Experiment over and near California (McNaughton et al., 2007). The submicron accumulation-mode particles that usually dominate $\mathrm{CCN}$ are sampled with nearly $100 \%$ efficiency. However, for a few exceptional cases with heavy dust or sea-salt concentrations encountered during the experiments, the data are more uncertain than for the rest of the periods (i.e. the scattering coefficient may be underestimated and its wavelength dependence overestimated).

An optical particle counter (OPC, a modified LAS-X, Particle Measurement Systems, Boulder, Colorado) measured the dry (RH controlled under $30 \%$ with a dilution flow) aerosol size distribution between $100 \mathrm{~nm}$ and about $20 \mu \mathrm{m}$ (Clarke, 1991). Its He-Ne laser operates at $633 \mathrm{~nm}$ detecting light scattered by individual particles over 35-145 degrees. The particle size was calibrated with polystyrene latex spheres with a refractive index of 1.59. For calibrating for the coarse mode, glass beads with a refractive index of 1.54 were also used. A size distribution was obtained every $3 \mathrm{~s}$, but averaged over $30 \mathrm{~s}$ to reduce noise due to low counting statistics at about $1 \mu \mathrm{m}$ and larger.

The number of aerosol particles measured with the OPC can be different from the number of particles larger than $100 \mathrm{~nm}$ because of imprecise sizing at the first OPC channel. 
The difference was estimated to be random and typically within $25 \%$ of the OPC number concentration, through comparison with the difference of two independent number counts, total condensation nuclei $(\mathrm{CN},>10 \mathrm{~nm}$ nominal detection size) and the DMA integral $(10-100 \mathrm{~nm}$, see below). No systematic bias with the presence of a specific aerosol component was evident.

Smaller particles with mobility diameters between 10 to $250 \mathrm{~nm}$ were measured with a Radial Differential Mobility Analyzer (DMA) under dry conditions. DMA samples were collected over $20 \mathrm{~s}$ and held in a lagged aerosol grab chamber (Clarke et al., 1998) for subsequent DMA analysis. The measured mobility distribution was inverted to an aerosol size distribution by taking into account the sampling line losses, bipolar charging probabilities, calibrated DMA transfer functions regarding DMA diffusion broadening and losses, and particle counting efficiencies (Zhou, 2001; Zhou et al., 2002). Physical morphologies other than sphere, which are common for freshly emitted combustion particles such as in fresh biomass burning plumes, can affect the DMA sizing (DeCarlo et al., 2004) but this effect was not considered.

Both DMA and OPC measurements allowed for realtime thermal analysis of particles at select temperatures to infer the size resolved chemical composition continuously throughout the aircraft campaigns. One of the analyses in this paper shows data collected for particles heated to $300^{\circ} \mathrm{C}$, and all other data are for unheated particles. The residence time in the heated section is a critical parameter for thermal denuder analyses (An et al., 2007; Huffman et al., 2008; Faulhaber et al., 2009). The plug flow residence time (PFRT) in the sections of nearly constant temperature for the $300^{\circ} \mathrm{C}$ channel was about one second.

Total and submicrometer aerosol scattering coefficients were measured at 450,550 and $700 \mathrm{~nm}$ using two TSI model 3563 integrating nephelometers (Anderson et al., 1996, 2003; Heintzenberg and Charlson, 1996). The measurements were made every second, but averaged over $30 \mathrm{~s}$ for the present study. The relative humidity in the instrument was not actively controlled but kept to $<30 \%$, often near $20 \%$, by ram heating and cabin temperatures higher than the ambient. The light scattering measured over the TSI nephelometer's detection angles of $7-170^{\circ}$ were corrected to $0-180^{\circ}$ based upon correction factors calculated from the OPC size distribution using Mie theory with the calibration particle refractive index as an approximation. Before this calculation, we confirmed that these two optical instruments operated consistently with each other: The scattering over $7-170^{\circ}$ derived from the OPC size distributions $(30 \mathrm{~s}$ average) over the study region agrees with the uncorrected nephelometer scattering within about $10 \%$, with the coefficient of determination $\left(R^{2}\right)$ being $0.83-0.89$ for the 3 wavelengths, as illustrated in the online supplementary material (Fig. S1 and Table S1: http://www.atmos-chem-phys.net/9/ 6727/2009/acp-9-6727-2009-supplement.pdf). The derived scattering Angstrom exponents $(-\Delta \log \sigma / \Delta \log \lambda$, where $\sigma$ is the scattering, and $\lambda$, the wavelength) mostly take values between 0 and 2.5 , and agree within 0.2 between the nephelometer and OPC. The calculated correction factor, $\sigma_{0-180^{\circ}} / \sigma_{7-170^{\circ}}$, lies between 1.0-1.1 for the Angstrom exponent of 2, indicating that the angular truncation requires a minor (0-10\%) adjustment for fine particles. The correction factor for coarse particles at the Angstrom exponent of 0 is larger: 1.7 for dust over Mexico and 1.3 for sea salt over the northeastern Pacific Ocean, both at $550 \mathrm{~nm}$. A 5-10\% variability is associated with the angular truncation correction factors for the entire observed range of Angstrom exponent. This variability is much larger than the error arising from gas calibration ( $\sim 1 \%$; Anderson et al., 1996) and manifests itself as a dominant part of the random error in the corrected dry scattering coefficient. The truncation correction factor is more uncertain for soot due to the distinctively different, and poorly known, refractive index. Column integral aerosol optical depth derived from the corrected scattering coefficient agreed well with independent observations (Rogers et al., 2009).

A prototype 3-wavelength Radiance Research particle soot absorption photometer (PSAP) continuously measured aerosol light absorption by monitoring the change in transmittance across a filter using an alternating 3-wavelength $(470,530$ and $660 \mathrm{~nm})$ LED. This filter-based measurement of absorption includes artifact response due to particulate light scattering (Bond et al., 1999). This is a function of the ratio of the scattering coefficient to the extinction coefficient (i.e. single scattering albedo, SSA) and the wavelength. We correct our data for the scattering artifact as well as calibration error after Virkkula et al. (2005). This correction is larger than the classic correction scheme widely used for a single-wavelength (at $530 \mathrm{~nm}$ ) prototype of the PSAP (Bond et al., 1999). We are unaware of the reason why the two correction schemes at an identical wavelength can differ by about $20 \%$ of the uncorrected absorption (see related discussions by Cappa et al., 2008). Because the absorption rarely exceeded $10 \%$ of the extinction, the absolute error in SSA is expected to be typically $<0.02$. The average instrument noise computed as the average standard deviation for six, $300 \mathrm{~s} \mathrm{(5} \mathrm{min)} \mathrm{averages} \mathrm{of} \mathrm{the} 1 \mathrm{~Hz}$ data taken in our laboratory for filtered air is $0.56 \mathrm{Mm}^{-1}$ for all wavelengths (McNaughton et al., 2009).

The CCN concentration was measured with a continuousflow $(0.5 \mathrm{~L} / \mathrm{min})$ streamwise thermal-gradient $\mathrm{CCN}$ counter manufactured by Droplet Measurement Technologies (Boulder, CO) (Roberts and Nenes, 2005; Lance et al., 2006). Sampled particles were exposed to a supersaturation established by a constant temperature gradient in the stream-wise direction along the vertical CCN column. Activated particles were detected by an optical particle counter at the exit of the column. The supersaturation was between $0.18 \pm 0.09 \%$, which corresponds to the lower end of the peak supersaturation in convective clouds (Pruppacher and Klett, 1980; Hudson and Svensson, 1995; Hoppel et al., 1996). A constant 
pressure controller was not deployed for this experiment; hence, only data from straight and level legs with constant ambient pressure are used for the analysis of the CCN data. The instrument supersaturation has been calibrated over the full range of pressures experienced during the campaigns.

An Aerodyne high-resolution time-of-flight aerosol mass spectrometer (HR-ToF-AMS, hereinafter "AMS") operated by the University of Colorado measured the mass concentration of submicron non-refractory aerosol species. In this paper "non-refractory" is empirically defined as those species that evaporate in a few seconds under high vacuum at $600^{\circ} \mathrm{C}$, and includes essentially all of the organic species and most sulfates and nitrates, including their ammonium salts. The AMS (DeCarlo et al., 2006) and the data that can be obtained from it (Canagaratna et al., 2007; Aiken et al., 2008) have been described previously in the literature. Briefly, the sampled particles are introduced in a vacuum chamber using an aerodynamic lens, and within $10 \mathrm{~ms}$ are vaporized at a resistively heated surface $\left(600^{\circ} \mathrm{C}\right)$. The resulting gas phase plume undergoes electron ionization $(70 \mathrm{eV})$, and is mass-analyzed using a high-resolution time-of-flight mass spectrometer $(\mathrm{H}$ TOF, Tofwerk, Thun, Switzerland). The resulting mass spectra are used to quantify the species mass concentrations using previously documented calibration and analysis methods (Jimenez et al., 2003; Allan et al., 2004; DeCarlo et al., 2006). For mass fractions of bulk aerosol composition the errors are generally about $10 \%$ except for very low aerosol concentrations. The AMS also recorded size distributions of the species, but this type of data is not used in the present paper. The AMS sampled through a separate inlet which had high transmission for submicron particles as characterized by Dunlea et al. (2008). More detailed discussion of AMS results during these campaigns are presented by DeCarlo et al. (2008), Dunlea et al. (2008), Aiken et al. (2007, 2008, 2009), Van Donkelaar et al. (2008), and Heald et al. (2008).

Size-resolved particle hygroscopicity was measured with the tandem differential mobility analyzer (TDMA) of Texas A\&M University (Gasparini et al., 2004; Tomlinson et al., 2007). Sequential measurements were made to characterize the growth of selected particles with dry (RH of $3.7 \pm 2.9 \%$ during MILAGRO and $2.3 \pm 2.2 \%$ during INTEX-B) diameters including 50, 100, 200 and $300 \mathrm{~nm}$. The voltage applied in the first DMA was fixed in order to select a monodisperse aerosol. This aerosol was then exposed to an elevated RH of about $84 \%$ (84.2 $\pm 2.3 \%$ during MILAGRO and $84.6 \pm 3.4 \%$ during INTEX-B). Subsequent to this conditioning, the initially monodisperse aerosol was introduced into the second DMA downstream, which scanned through the particle sizes. The measured size distribution is described in terms of the relative change in diameter of the particles, i.e. their growth factor. For a given aerosol distribution, several growth factor modes may be observed when multiple particle types are present. Any scan in which the relative humidity deviated by more than $4 \%$ below or $6 \%$ above $84 \%$ RH was discarded. The "growth" factor for dry particles exposed to the dry RH in the conditioning section was usually found to be within $1 \%$ of the expected value (1.00), which provides an indication of the measurement accuracy.

\subsection{Data processing}

When combining data from multiple instruments throughout this paper, we excluded cases where the particle light scattering varied widely - the standard deviation exceeding half of the mean - within each 30-s averaging time period. This reduces the influence of a change in aerosol properties introduced by temporal mismatch among the instruments, for example, the 10-s gap between a 20-s DMA sampling and a 30 -s OPC cycle.

\section{Observed CCN critical dry diameter and its relationship with bulk aerosol chemical composition}

A common method of deriving $\mathrm{CCN}$ concentration is to integrate dry particle number size distribution from the critical dry diameter, $D_{d}$. We estimate $D_{d}$ independently from two measurements, CCN counts (Sect. 3.1) and hygroscopicity (Sect. 3.2), before evaluating the results against bulk aerosol chemical composition (Sect. 3.3).

\subsection{Estimating $D_{d}$ from $\mathrm{CCN}$ counts}

Here $D_{d}$ is estimated by seeking consistency between the simultaneous measurements of the total CCN concentration and the dry aerosol size distribution. To illustrate this approach, Fig. 2a compares the CCN concentration at 0.15$0.20 \%$ supersaturation and the OPC number integrated from $100 \mathrm{~nm}$, both measured on the $\mathrm{C} 130$ aircraft over Central Mexico and averaged over $30 \mathrm{~s}$. The $D_{d}$ is estimated to be $100 \mathrm{~nm}$ for the data points exactly on the 1:1 line where the number integral from $100 \mathrm{~nm}$ agrees with the $\mathrm{CCN}$ concentration. This approximation assumes the diameter cut is sharp such that all particles above it, and none below, are activated, as if particles were homogeneously mixed. The data points above the 1:1 line represent cases with $D_{d}>100 \mathrm{~nm}$ (some particles larger than $100 \mathrm{~nm}$ were not activated as CCN) and those below the line, $D_{d}<100 \mathrm{~nm}$. Similar exercises were made for threshold diameters other than $100 \mathrm{~nm}$. For threshold diameters smaller than $100 \mathrm{~nm}$ the DMA distribution was combined with the OPC. It should be noted that $D_{d}$ is overestimated if there is a significant fraction of nonhygroscopic particles above the diameter. A better way to know $D_{d}$ is by varying the dry particle size transmitted to the CCN counter and simultaneously monitoring the total number of particles (both activated and unactivated) to get an activation curve, though this is difficult to carry out on a fast-moving platform with our available instrumentation. Meanwhile, as aircraft survey large regions, they encounter a diverse mix of aerosol characteristics. Our intent is to capture approximated features to characterize dominant tendencies. 

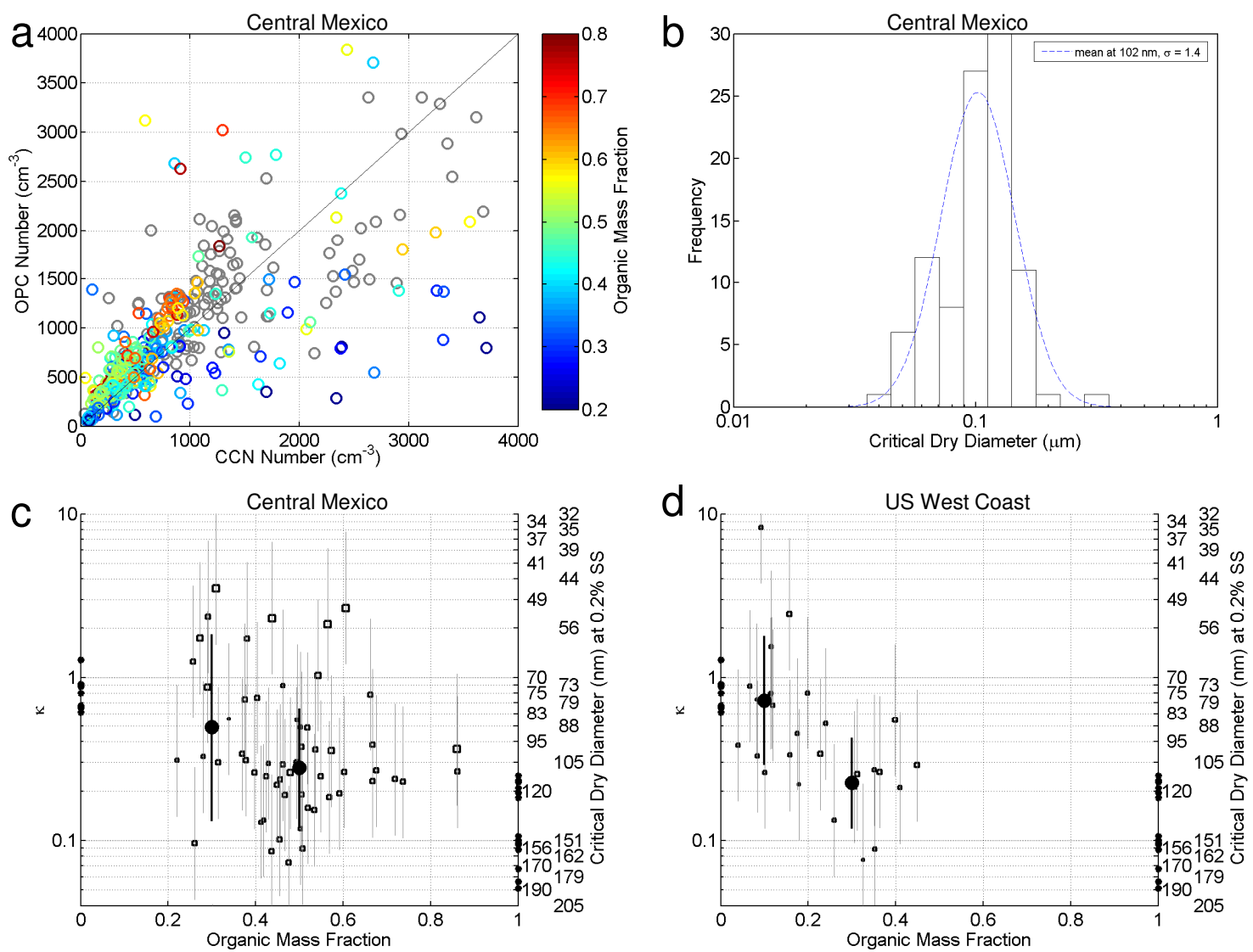

Fig. 2. (a) Comparison of the OPC number integral and the CCN concentration measured over Central Mexico and averaged over $30 \mathrm{~s}$. The OPC number is the integral of size distribution between $100 \mathrm{~nm}$ and $20 \mu \mathrm{m}$. The CCN concentration shown here was measured under supersaturation of $0.15-0.20 \%$. Marker color indicates the AMS organic fraction of submicron non-refractory aerosol mass, and is grey where no AMS data are available. (b) A histogram of the critical dry diameter derived from the CCN measurements. (c) The hygroscopicity parameter, $\kappa$, derived from the CCN counter measurements compared to the AMS organic mass fraction. The size of square markers is made proportional to the $\mathrm{CCN}$ concentration. The grey vertical lines indicate estimated measurement uncertainty. The dots represent the geometric mean and standard deviation within 0.2 organic mass fraction bins. (d) Same as (c) but for the US West Coast.

The value of $D_{d}$ estimated this way was adjusted to a fixed $0.20 \%$ supersaturation using Kohler theory which describes a linear relationship with a slope of $-3 / 2$ between the critical diameter and supersaturation both on logarithmic scales. For example, the $D_{d}$ estimated from a measurement at $0.15 \%$ supersaturation was decreased by $17 \%$, reflecting the fact that aerosols of identical chemical properties would activate at this smaller diameter if brought to $0.20 \%$ supersaturation. Note this technique can only be applied for a small change in supersaturation. At higher supersaturations smaller particles will activate, and these particles may have a substantially different chemical composition and mixing state.

A lognormal fit to the frequency distribution of these adjusted $D_{d}$ values peaks at $102 \mathrm{~nm}$, with a geometric standard deviation (sigma) of 1.4 (Fig. 2b). This apparent variation in $D_{d}$ is partially attributable to measurements uncertainties in supersaturation and sizing. The supersaturation of the $\mathrm{CCN}$ counter can be inaccurate by up to $20 \%$ (Rose et al., 2008a).
This translates into a precision in critical diameter of $\sim 12 \%$, based on the $-3 / 2$ linear relationship mentioned above. The combined sizing error, on the other hand, is about $25 \%$ in terms of particle number (Sect. 2.2), equivalent to an error in $D_{d}$ up to $20 \%$ depending on the shape of size distribution. The variability in the aerosol number during the course of each $30 \mathrm{~s}$ measurement time period is similar or smaller. The $\mathrm{CN}$ counts indicate that it is $20 \%$ in number, which corresponds to a $\sim 15 \%$ change in $D_{d}$. Because these uncertainties should be random and independent of each other, the overall precision in the derived $D_{d}$ is the square root of sum of the squares of them, which is $25-30 \%$.

This estimated measurement uncertainty in $D_{d}$ is smaller than its apparent variation $(\sim 40 \%)$. This indicates that the natural variability in the critical diameter is about $30 \%$, because the observed variability should be the addition in quadrature of the actual variability and the random error This implies that, any fixed value assumed for $\mathrm{CCN}$ critical 

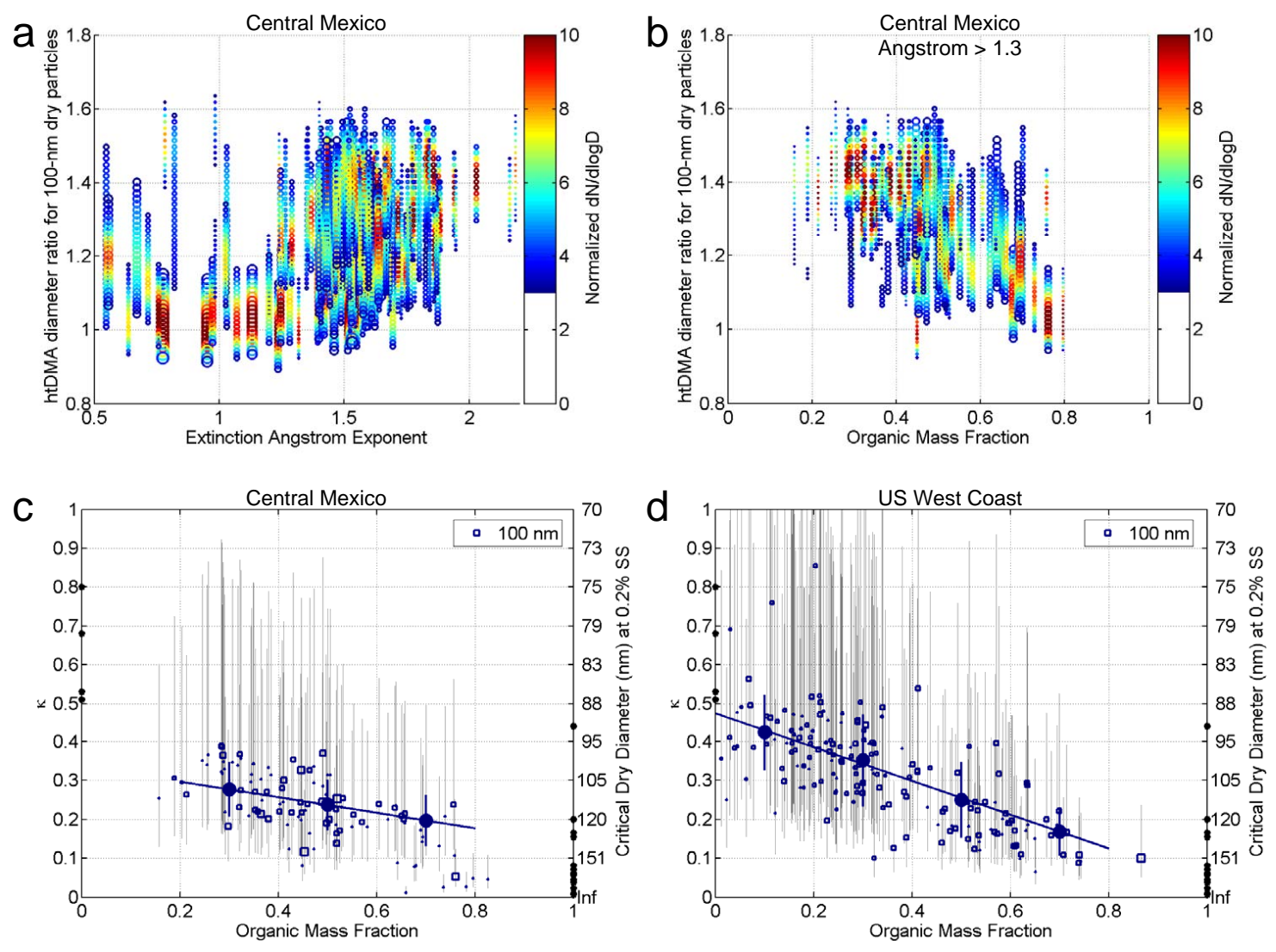

Fig. 3. (a) Growth factor measured with the tandem differential mobility analyzer aboard the C130 aircraft over Central Mexico for the particles with a dry diameter of $100 \mathrm{~nm}$, plotted against the extinction Angstrom exponent. The higher relative humidity was set to $\sim 84 \%$. The red and blue colors indicate relatively high and low number fractions, respectively, of the selected dry particles that exhibited the particle hygroscopicity. The marker size is set proportional to the dry extinction coefficient at $530 \mathrm{~nm}$. (b) The growth factor for the data with Angstrom exponent greater than 1.3 only, plotted against the AMS organic mass fraction. (c) The hygroscopicity parameter, $\kappa$, derived from the TDMA measurements with a dry selected diameter of $100 \mathrm{~nm}$ plotted against the AMS organic mass fraction, for all data regardless of Angstrom exponent. The size of square markers is made proportional to the OPC number integral, a proxy for CCN concentration. The grey vertical lines indicate estimated measurement uncertainty. The large dots and associated bars represent the mean and standard deviation within 0.2 organic mass fraction bins. The small black dots on the vertical axes indicate values tabulated by Petters and Kreidenweis (2007). (d) Same as (c) but for the US West Coast.

dry diameter over the wide geographical region without consideration of the chemical composition is associated with a typical error of no less than about $30 \%$. This conclusion from our data over Central Mexico appears to apply to those over the US West Coast as well, though the smaller number of data points makes us somewhat less confident. The largest $90 \%$ of $D_{d}$ derived for the US West Coast forms a lognormal distribution centered near $100 \mathrm{~nm}$ with a geometric standard deviation near 1.4. The rest forms a prolonged tail over small diameters $(15-40 \mathrm{~nm})$, a feature not evident in the Central Mexico data (Fig. 2b), which further discourages the use of a single fixed value of critical dry diameter. For both regions, more constraints on $D_{d}$ are desirable, and are pursued in Sect. 3.3 by evaluating it against the organic mass fraction (Fig. 2c and d).

\subsection{Estimating $D_{d}$ from hygroscopicity}

The critical diameter $D_{d}$ can also be estimated from the particle hygroscopicity measured below saturation with the TDMA, as a result of its relationship with the CCN activity above saturation, though slightly soluble compounds and surface active species may behave differently between the two humidity domains. The measured mobility diameter growth in response to water uptake, i.e. the humidified diameter divided by the dry one, is plotted over the vertical axis of Fig. 3a and $b$. The concentration density is indicated by color. (The horizontal axis will be discussed in Sects. 3.3 and 4.2.) The growth factor is seen to typically range from 1 (low hygroscopicity) to 1.6 (high). An inhomogeneous mix of particles can result in more than one peak on the growth factor distribution. 
To derive $D_{d}$ for each TDMA distribution, the following equation from Petters and Kreidenweis (2007):

$S(D)=\frac{D^{3}-D_{d}^{3}}{D^{3}-D_{d}^{3}(1-\kappa)} \exp \left[\frac{4 \sigma M_{w}}{R T \rho_{w} D}\right]$

was solved for $\kappa$, the hygroscopicity parameter. $S$ is the saturation ratio over an aqueous solution droplet (0.84), $D$ and $D_{d}$ the humidified and dry diameters, respectively, $\sigma$ the surface tension at an air/pure water interface $\left(0.072 \mathrm{~J} \mathrm{~m}^{-2}\right), M_{w}$ the molecular weight of pure water $\left(18 \mathrm{~g} \mathrm{~mol}^{-1}\right), R$ the gas constant $\left(8.3 \mathrm{~J} \mathrm{~K}^{-1} \mathrm{~mol}^{-1}\right), T$ the temperature $(\sim 298 \mathrm{~K})$, and $\rho_{w}$ the density of water $\left(\sim 1 \mathrm{~g} \mathrm{~cm}^{-3}\right)$. Note that we ignore the effect of organics on the surface tension on purpose so that all chemical effects are lumped into $\kappa$. In other words, the $\kappa$ values derived this way have to be regarded as "effective hygroscopicity parameters" that account not only for the reduction of water activity of the solute ("effective Raoult parameters") but also for surface tension effects (Petters and Kreidenweis, 2007; Rose et al., 2008b; Pöschl et al., 2009; Gunthe et al., 2009). The hygroscopicity parameter is linked to $D_{d}$ by:

$$
\begin{aligned}
& \kappa=\frac{4 A^{3}}{27 D_{d}^{3} \ln ^{2} S_{c}} \\
& A=\frac{4 \sigma M_{w}}{R T \rho_{w}}
\end{aligned}
$$

where $S_{c}$ is the saturation ratio for which the critical dry diameter is derived. Substituting the applicable numbers into these two equations (with no experimental results involved), the relationship between $\kappa$ and $\mathrm{D}_{d}$ under $0.2 \%$ supersaturation for our conditions is

$D_{d}=\kappa^{(-1 / 3)} \cdot 70 \mathrm{~nm}$

For very hygroscopic aerosol similar to ammonium sulfate and sodium chloride the hygroscopicity parameter $\kappa$ is near $1\left(D_{d} \sim 70 \mathrm{~nm}\right)$ and for low hygroscopicity typical of many organics $\kappa$ is near $0.1\left(D_{d} \sim 151 \mathrm{~nm}\right)$. The precision in the estimated diameter was determined to be $\sim 20 \%$ based on the random uncertainty in the TDMA relative humidity (assumed to be 3 percentage points) and the random sizing error ( $2 \%$ of the nominal size).

The estimated geometric mean critical dry diameters for $\mathrm{CCN}$ activation are 109,121, 117 and $110 \mathrm{~nm}$ when using as input the measurements with dry diameters of 50, 100, 200 and $300 \mathrm{~nm}$, respectively, with a geometric standard deviation (sigma) of 1.1-1.2. The same analysis applied to the data taken over the US West Coast results in the geometric mean diameter of 110, 106, 90 and $96 \mathrm{~nm}$ for the 4 dry diameters, respectively, with a standard deviation of 1.1-1.2. The critical diameter varies with aerosol chemical composition, as discussed below.

\subsection{The relationship of $D_{d}$ with organic mass fraction of submicron aerosols}

According to Kohler theory, $D_{d}$ depends on the aerosol chemical composition at a given supersaturation. Here we evaluate the strength of this relationship in our data. As a proxy for bulk aerosol chemical composition we use the OMF obtained from the C130 AMS measurements of nonrefractory components of submicron aerosols, the size most relevant to $\mathrm{CCN}$ activation. Although refractory components are not measured by the AMS, black carbon and dust comprised only a small mass fraction of the submicron range in and around Mexico City (Aiken et al., 2009; Subramanian et al., 2009) so that the OMF calculated here is still approximately representative of the true OMF of the submicron mode.

The particle growth factor tends to be high under low OMF (Fig. 3b), consistent with trends reported by Quinn et al. (2005) and the fact that the main non-organic components of the submicron mode are inorganic salts (DeCarlo et al., 2008). Somewhat less clearly, the marker color of Fig. 2a indicates that the $\mathrm{CCN}$ concentration tends to exceed the OPC integral number under low OMF (high sulfate, nitrate and ammonium) over Central Mexico, especially for CCN concentration larger than $\sim 500 \mathrm{~cm}^{-3}$. This observation suggests that organic particles were less effectively activated than sulfate and nitrate particles near $100 \mathrm{~nm}$ in general.

The derived critical dry diameter is a more direct and convenient parameter than the number concentration and the growth factor for the purpose of examining the $\mathrm{CCN}$ activity of particles. Squares in Fig. 3c illustrate the relationship between $D_{d}$ deduced from the TDMA data for the dry diameters of $100 \mathrm{~nm}$ and OMF, with the grey vertical lines indicating the estimated measurement errors. Petters and Kreidenweis's (2007) hygroscopicity parameter, $\kappa$, estimated from the same TDMA measurements is also shown in the left vertical axis to facilitate adjustment of $D_{d}$ to different supersaturations (see Sect. 3.2 for the definition of $\kappa$ ). Scatter plots for the other TDMA dry diameters $(50,200$ and $300 \mathrm{~nm})$ are given online (Figs. S2 and S3: http://www.atmos-chem-phys.net/9/6727/ 2009/acp-9-6727-2009-supplement.pdf).

To quantify the dependency, $\kappa$ averaged over each 0.2 OMF bin are superimposed as circles in Fig. $3 \mathrm{c}$ for Central Mexico and Fig. 3d for the US West Coast for dry $100 \mathrm{~nm}$ particles, and shown in Fig. 4 for all TDMA sizes to facilitate comparisons. The OMF- $\kappa$ relationship approximated by linear regression through the bin average is also depicted in these figures, and parameterized in Table 1 . Values of $\kappa$ reported previously for various ionic and organic species and tabulated by Petters and Kreidenweis (2007) are represented by black dots. 

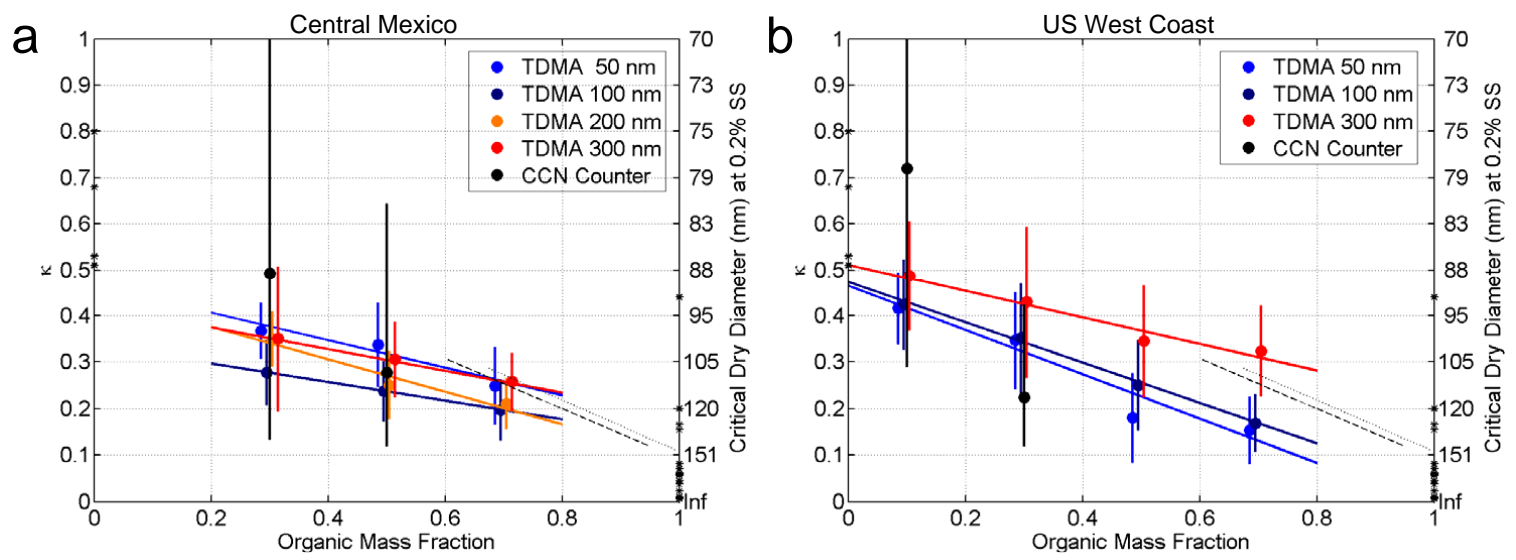

Fig. 4. The mean and standard deviation within 0.2 organic mass fraction bins of the hygroscopicity parameter, $\kappa$, derived from the TDMA and CCN counter measurements plotted against the AMS organic mass fraction for Central Mexico (a) and the US West Coast (b). See Table 1 for expression of the fit lines. The dashed and dotted curves represent the AMS measurements (integral and size-resolved, respectively) and particle hygroscopicity in Amazon (Gunthe et al., 2009).

Table 1. Fit to the aerosol hygroscopicity/chemical composition relationship.

\begin{tabular}{ccc}
\hline$D_{d}(\mathrm{~nm})$ & $\kappa$ & $\mathrm{RMS}$ \\
\hline \multicolumn{3}{c}{ Central Mexico } \\
50 & $0.47-0.30 \times \mathrm{OMF}$ & 0.073 \\
100 & $0.34-0.20 \times \mathrm{OMF}$ & 0.060 \\
200 & $0.44-0.35 \times \mathrm{OMF}$ & 0.070 \\
300 & $0.42-0.23 \times \mathrm{OMF}$ & 0.094 \\
& US West Coast \\
50 & $0.46-0.48 \times \mathrm{OMF}$ & 0.096 \\
100 & $0.47-0.43 \times \mathrm{OMF}$ & 0.096 \\
200 & $\mathrm{~N} / \mathrm{A}$ & $\mathrm{N} / \mathrm{A}$ \\
300 & $0.51-0.29 \times \mathrm{OMF}$ & 0.135 \\
\hline
\end{tabular}

$D_{d}$ is the dry diameters selected with the TDMA, OMF is the organic mass fraction of non-refractory component of submicron aerosols, $\kappa$ is the hygroscopicity parameter, RMS is the root mean square of the differences in $\kappa$ between the fit and the individual data. See Figs. 3c, $d$ and 4 for the fit lines, and Table S2: http://www.atmos-chem-phys.net/9/6727/ 2009/acp-9-6727-2009-supplement.pdf online for a similar analysis on $\log _{10} \kappa$.

The critical diameter generally increases, and $\kappa$ decreases, as the OMF increases, as expected from the lower solubility of organic compounds relative to the inorganic. A closer look at Fig. 4 reveals subtle variations in the OMF- $\kappa$ relationships with region and particle size. Compared with Central Mexico, the US West Coast exhibits higher variation in the particle hygroscopicity with both size and chemical composition. This perhaps reflects the more diverse sources of particles (Central Valley pollution of urban and agricultural mix, Asian fossil fuel and biomass combustion, and possibly ocean surface) sampled over and off the US West Coast, compared to Central Mexico's air predominantly influenced by local combustion processes. In fact, the hygroscopicity tends to be higher for samples from California than those from the State of Washington for OMF greater than 0.6, indicating a wide variety of organic particles present over the West Coast. We do not know why the dry $50 \mathrm{~nm}$ particles are less hygroscopic over the US West Coast than over Central Mexico, for $\mathrm{OMF}=0.4-0.8$. The organics sampled in Asian plumes over the West Coast were essentially all aged and oxygenated (OOA-1) (Dunlea et al., 2008; Ulbrich et al., 2009), whereas the organics over Central Mexico were mostly a combination of fresher and aged oxygenated (OOA2 and OOA-1) (Aiken et al., 2008; DeCarlo et al., 2008). More oxygenated organics are thought to be more hygroscopic. It is possible that the apparent discrepancy in the hygroscopic growth for the $50 \mathrm{~nm}$ particles between the two regions is due to some potassium in the biomass burning particles in Mexico, which is excluded from the calculation of OMF. For high OMF cases affected by biomass burning, the OMF could be overestimated and the data points for Central Mexico at high OMF should move to the left in the figure.

The dependence we observed is approximated as

$\kappa=0.34-0.20 \times \mathrm{OMF}$ for Central Mexico

$\kappa=0.47-0.43 \times \mathrm{OMF}$ for the US West Coast

for dry $100 \mathrm{~nm}$ particles (Table 1 ). These equations give $\kappa$ of 0.34 and 0.14 at $\mathrm{OMF}=0$ and 1 , respectively, for Central Mexico, and $\kappa$ of 0.47 and 0.04 for the US West Coast. Our mean $\kappa$ values may be systematically biased because of our inexact assumption of homogeneous internal mixing as mentioned before, but hardly because of instrument errors. As noted in Sect. 2.2, the measurement error associated with the number count is random and not biased by aerosol chemical 
composition. Measurement errors in the $\mathrm{CCN}$ concentration and TDMA growth factor too are likely random.

For Amazon's air masses sampled from a 39-m-tall tower Gunthe et al. (2009) expressed $\kappa$ as $0.1 X_{\mathrm{m}, \text { org }}+0.6 X_{\mathrm{m} \text {,inorg }}$ where $X_{\mathrm{m} \text {,org }}$ and $X_{\mathrm{m} \text {,inorg }}$ are organic and inorganic mass fractions, or OMF and (1-OMF), respectively. Their more precise expressions, representing two different methods of selecting particle sizes, are shown in Fig. 4. This fit, derived from their data taken mostly under $X_{\mathrm{m} \text {, org }}$ of $0.65-0.95$, falls within the variability of our individual observations even over the range of low OMF values that they did not sample (our expressions are based on observations over $\mathrm{OMF}=0.2-$ 0.8 for Central Mexico, $0-0.8$ for the US West Coast). This is in spite of noticeable differences in chemical composition, e.g. less nitrate and, presumably, dust over Amazon than over Central Mexico. To be precise, we found that $\kappa$ is less sensitive to the OMF, starting from values near 0.3-0.5, rather than 0.6, at $\mathrm{OMF}=0$. Our $\kappa$ values extrapolated to $\mathrm{OMF}=1$ are similar to the values near 0.1 reported for Amazon (Gunthe et al., 2009) and chamber-generated secondary organic aerosols (King et al., 2007). The smaller variation in our $\kappa$ with OMF is most notable with Central Mexico (at all dry particle sizes) and the US West Coast $300 \mathrm{~nm}$ particles.

The wider range of OMF, $0-0.8$, for our research areas (particularly the US West Coast) means that aerosol composition will be more critical for estimation of $\mathrm{CCN}$ concentration than at the fixed sites previously studied (Dusek et al., 2006; Gunthe et al., 2009). As a crude estimate of the sensitivity of CCN concentration to aerosol chemical composition, the integral of our US West Coast size distributions from $D_{d}$ is typically twice as large for $D_{d}=90 \mathrm{~nm}(\kappa \sim 0.5)$ as that for $D_{d}=140 \mathrm{~nm}(\kappa \sim 0.1)$. These critical diameters correspond to OMF of 0 and 0.8 , respectively, for the dry $100 \mathrm{~nm}$ particles. The variation in the CCN concentration estimated in this manner for the US West Coast would not be as large as a factor of 2 but near $30 \%$, if the OMF did not go below $0.6\left(D_{d}=120 \mathrm{~nm}, \kappa \sim 0.2\right)$.

The variability in $D_{d}$ apparent at any given OMF, once adjusted for the measurement error, provides an estimate of uncertainty in bulk-composition-based $D_{d}$ observations. For the calculation of relative variability, fit lines for $\log _{10} \kappa$ instead of $\kappa$ were made against OMF (see Figs. S4 and S5, Table S2 of the online supplement: http://www.atmos-chem-phys.net/9/6727/ 2009/acp-9-6727-2009-supplement.pdf). Using the root mean square of the differences in $\log _{10} \kappa$ between this new fit and the individual data, we represent the apparent relative variability in $\kappa$ by $\left(10^{\text {RMSlog }}-1\right) \times 100 \%$. The variability is $25-50 \%$ depending on the dry particle diameter $(\sim 35 \%$ for $100 \mathrm{~nm}$ particles), a range expected from the RMS of the linear fit (Table 1), This $\kappa$ variability translates into an $8-14 \%$ variation in $D_{d}$. This degree of deviation from the fit is smaller than the estimated measurement uncertainty of $\sim 20 \%$ in $D_{d}$ (Sect. 3.2), even without considering the likely exaggeration due to the $\sim 10 \%$ measurement uncertainty in
OMF (Sect. 2.2). That implies that the natural variability in critical dry diameter at a given OMF is much smaller than $\sim 20 \%$.

That means, as far as the aerosols sampled from our aircraft are concerned, the CCN activity of particles does not noticeably vary among the ionic species, organic species or mixing states (e.g. the possible intermittent presence of externally-mixed nonhygroscopic particles). As detailed in DeCarlo et al. (2008), our aircraft sampled pollution particles of a wide age range, including fairly fresh ( $<1$ day old) urban pollution, aged ( $1-5$ days old) outflow and biomass burning particles. The mass ratio of sulfate to all non-refractory ionic species spanned widely (between 0.1 and 0.8 for the time periods assessed in the present paper), owing to the various sulfate sources including volcanoes and petrochemical/power plants compared to mainly urban sources of nitrate. Existence of numerous organic species of different origin has been revealed by the AMS. The mixing state, though not directly measured throughout the experiment, might also be highly variable. It is very useful that the OMF constrains $D_{d}$ to such a small range of values for a collection of aerosols of unknown detailed chemical properties and state of mixing. The results presented here may not apply at higher supersaturations with activation of smaller particles that are more likely to vary in concentration and composition.

Meanwhile, the $D_{d}$ derived from the CCN counter measurements shown in Fig. $2 \mathrm{c}$ and $\mathrm{d}$ is more variable than those based on the TDMA measurement (Fig. $3 c$ and d). As the vertical black bars indicate, the apparent variability in $D_{d}$ for each bin average value exceeds half a logarithmic decade, significantly larger than those for the TDMA-based measurements. At a given $\mathrm{OMF}$ the $\mathrm{CCN}$-counter-based $\kappa$ varies by a factor of 3-4, which translates into a $50-60 \%$ variation in $D_{d}$. This is largely caused by pressure variations in the CCN column, in which a constant pressure controller was not installed during our experiments. The derived $D_{d}$ tends to be small especially when the $\mathrm{CCN}$ concentration exceeds $1000 \mathrm{~cm}^{-3}$ over Central Mexico, as seen for 10 cases (or $16 \%$ of the data associated with concurrent measurements of AMS and size distributions) represented by relatively large squares in Fig. 2c. This happened when the OMF took moderate values between 0.3 and 0.6 , not the low values for which $D_{d}$ is expected to be small. Even so, the average appears to agree reasonably with the TDMA estimates (Fig. 4).

In summary, $D_{d}$ for $0.2 \%$ supersaturation is near $100 \mathrm{~nm}$ over Central Mexico and the US West Coast, and correlated with the OMF over $0.2-0.8$ and $0-0.8$ respectively. If the critical dry diameter at a given OMF value varies by much less than 20\%, as our TDMA measurements suggest, knowledge of the OMF would certainly improve estimation of CCN concentration. 

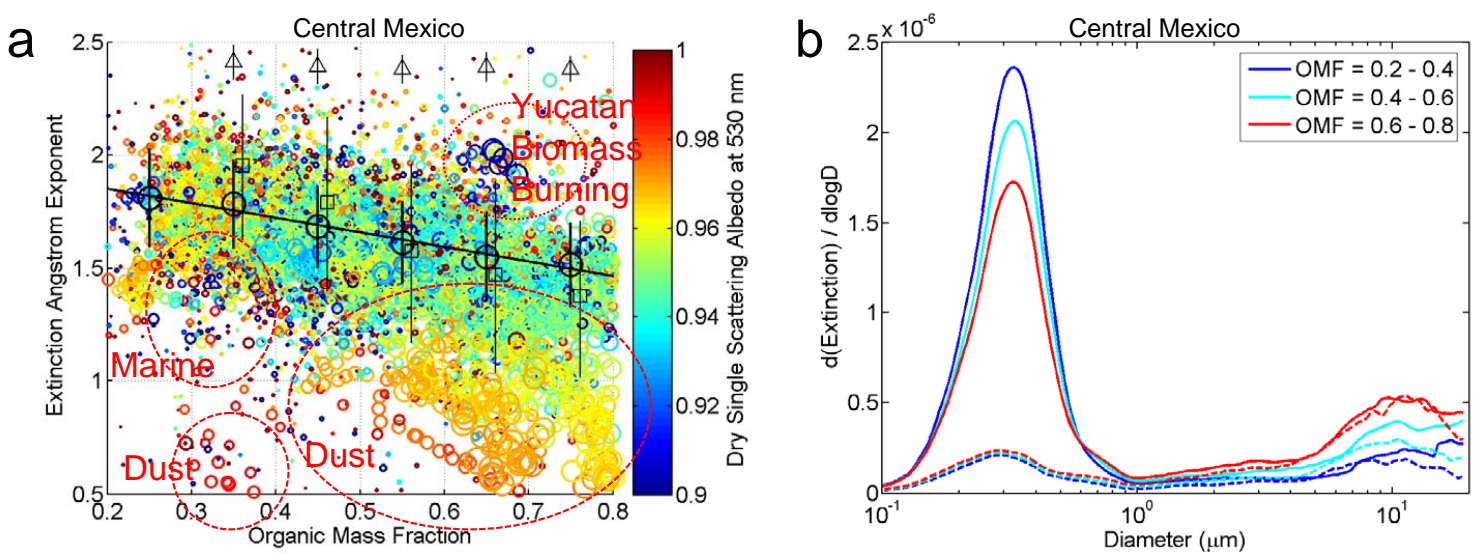

Fig. 5. (a) The relationship between the organic mass fraction (OMF) and the nephelometer extinction Angstrom exponent observed over Central Mexico and averaged over $30 \mathrm{~s}$. Marker size is proportional to the dry extinction coefficient $\left(\mathrm{Mm}^{-1}\right)$ at $530 \mathrm{~nm}$. The linear regression (thick black line) is made for the mean values (thick black circles) over 0.1 OMF bins for the Mexico pollution data excluding other types of air mass (red circles, detailed in text). Also shown are the values of Angstrom exponent calculated from the OPC 30-second-average size distribution for unheated total (thin squares) and submicron (thin triangles) pollution particles, averaged in each OMF bin. The vertical bars indicate the one standard deviation variability. (b) Normalized extinction size distribution averaged for three classes of OMF, 0.2-0.4, 0.4-0.6 and 0.6-0.8. The solid and dashed curves are for the unheated and heated (to $300^{\circ} \mathrm{C}$ ) particles, respectively.

\section{Optical signatures of the organic mass fraction and hygroscopicity}

\subsection{Optical signatures of the organic mass fraction}

Remote-sensing-based estimates of bulk aerosol chemical composition, which would facilitate inference of $\mathrm{CCN}$ activity as discussed in the previous section, requires welldefined relationships between aerosol optical and chemical properties. Few examples of such relationships are known. Both ionic and organic compounds typically reside in the accumulation mode and have similar values of refractive index, resulting in similar light scattering efficiency and wavelength dependence between them. Over Central Mexico, however, the wavelength dependences of light extinction and absorption can help differentiate aerosol components, as demonstrated below.

\subsubsection{Wavelength dependence of extinction}

Several remote-sensing instruments are capable of retrieving the Angstrom exponent of extinction $(-\Delta \log \sigma / \Delta \log \lambda$, where $\sigma$ is the extinction, and $\lambda$, the wavelength), albeit on a column integral basis (Remer et al., 2006; Kahn et al., 2005). If related to the Angstrom exponent, aerosol chemical properties such as the organic mass fraction (OMF) may be estimated from space-borne and ground-based optical measurements.

Our observations over Mexico reveal that the Angstrom exponent of dry aerosol extinction has a linear relationship with the OMF (Fig. 5a). The outliers, circled in the figure, were identified not only by the optical properties (the extinction Angstrom exponent and the SSA at $530 \mathrm{~nm}$ ) but also by air mass location and relative humidity (not shown). The most prominent outlier is the dust, characterized by the extinction Angstrom exponent smaller than 1.3 and SSA near 0.98. The coarse/submicron volume ratio derived from the OPC size distribution (not shown) generally exceeds 20 for these samples. Another outlier group, the marine aerosols sampled over Gulf of Mexico over 0-2 km above sea level also had low extinction Angstrom exponent, indicative of coarse sea salt particles. Sulfate mass presumably derived from precursors of oceanic origin and possibly from the volcanic and refinery sources nearby (DeCarlo et al., 2008) kept the organic fraction of submicron marine aerosols low $(<\sim 0.4)$. Furthermore, the air masses sampled to the east of $94^{\circ} \mathrm{W}$ had high Angstrom exponents and generally high OMF, as expected for biomass burning plumes that dominated the observed aerosol concentrations when sampling near and over the Yucatan peninsula (Yokelson et al., 2009). Satellite algorithms are likely to identify these outliers by their geographical location and wavelength dependence, as well as ancillary model or satellite information of surface wind speed, humidity, existence of elevated plumes and other environmental parameters.

After excluding these air mass types, our Central Mexico pollution data show a clear anti-correlation. A fit of the extinction Angstrom exponent, $A_{\text {ext }}$, to the median values in OMF bins with a width of 0.1 is

$A_{\text {ext }}=-0.70 \times \mathrm{OMF}+2.0$

This linear regression, if extrapolated, reaches extinction Angstrom exponent of 2.0 and 1.3 for completely ionic and organic non-refractory aerosols, respectively. 

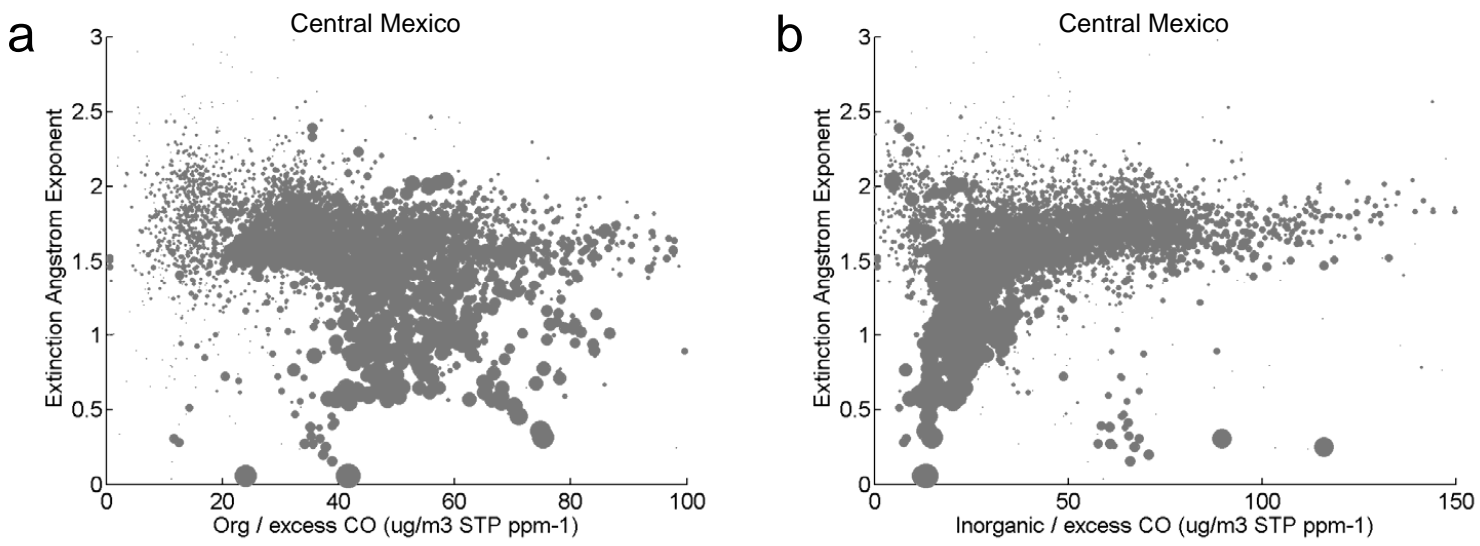

Fig. 6. Mass of (a) organic and (b) inorganic (sum of sulfate, nitrate and ammonium) materials of non-refractory submicron aerosols measured over Central Mexico with the AMS and normalized by the 30-second-average excess carbon monoxide concentration, compared with the wavelength dependence of light extinction. Marker size is proportional to the dry extinction coefficient $\left(\mathrm{Mm}^{-1}\right)$ at $530 \mathrm{~nm}$.

The equation above, in a reversed form $\left(\mathrm{OMF}=-\left(A_{\mathrm{ext}}-2.0\right) / 0.70\right)$, predicts the organic mass fraction for a known value of extinction Angstrom exponent. The root mean square (RMS) of the difference between the observed and fitted OMF values, a measure of the predictability, is 0.3. In terms of the sulfate mass fraction (SMF) $A_{\text {ext }}$ is $0.5 \times \mathrm{SMF}+1.5$, with an RMS of the SMF difference of 0.4 . The submicron non-refractory nitrate fraction shows an even weaker relationship with the Angstrom exponent. The Angstrom exponent for ambient (not necessarily dry) aerosols would relate to the OMF similarly. This is because, unless the $\mathrm{RH}$ is higher than $95 \%$, humidity changes do not significantly influence the wavelength dependence, because the scattering coefficients at all wavelengths change by similar factors and because absorption is usually a minor fraction of extinction. According to a simulation of diameter growth factor using the size distributions over North America (Shinozuka et al., 2007) and another similar calculation (Anderson et al., 2005), the absolute difference in Angstrom exponent between dry and ambient conditions is 0.2 or smaller, unless both the humidity response and the dry Angstrom exponent exceed $\sim 2$.

In the rest of this section we attempt to ascertain the cause for the anti-correlation between OMF and extinction Angstrom exponent. First we demonstrate that the observed relationship is a manifestation of coexistence of coarse particles and submicron organic masses over the region. Then we discuss potential causes of their link.

The presence of coarse particles predictably dominates the variation in the Angstrom exponent. The OPC size distribution averaged over the entire experiment over Central Mexico for different OMF values $(0.2-0.4,0.4-0.6,0.6-0.8)$ are shown in Fig. 5b. The size distribution of extinction was computed with Mie theory with a constant refractive index of 1.59 , divided (normalized) by the simultaneously measured nephelometer total scattering coefficient and averaged. Concentrations of both unheated and heated (to $300^{\circ} \mathrm{C}$ ) particles are enhanced above $5 \mu \mathrm{m}$, particularly for the highest OMF bin. Consistently, the calculated Angstrom exponent (thin squares in Fig. 5a) matches the nephelometerbased Angstrom exponent within 0.2, and varies almost as widely if a little more steeply with the OMF. In contrast, that calculated for OPC particles up to $750 \mathrm{~nm}$, which roughly corresponds to $1 \mu \mathrm{m}$ aerodynamic diameter, varies between 2.3 and 2.5 (thin triangles in Fig. 5a), a range narrower than observed. Hence, the Angstrom exponent in this geographical region is determined by coarse particles (particles larger than $1 \mu \mathrm{m}$ ), not by the variation in aerosol composition within the submicron size range, such as varied mixes of the organic and ionic species of slightly different size.

Low wavelength dependence was typically associated with relatively high organic and low inorganic mass in submicron aerosols. Figure 6 compares the extinction Angstrom exponent with the mass of submicron nonrefractory organic/inorganic material divided by excess $\mathrm{CO}$ (total $\mathrm{CO}$ minus the background value, the latter varying around $\sim 0.07$ ppmv from flight to flight; DeCarlo et al., 2008). The relative organic mass often exceeded $40 \mu \mathrm{g} \mathrm{m}^{-3} \mathrm{STP} \mathrm{ppm}^{-1}$, and the relative inorganic mass seldom exceeded $30 \mu \mathrm{g} \mathrm{m}^{-3} \mathrm{STP} \mathrm{ppm}^{-1}$, when the extinction Angstrom exponent was near or below 1.3. This is in contrast to cases with high Angstrom exponent where mass of each component took a wider range of values.

The cause for the coexistence of coarse particles and submicron organic mass is, meanwhile, unclear. Dust has been observed to effectively take up aerosol precursors such as sulfur dioxide $\left(\mathrm{SO}_{2}\right)$, nitrogen dioxide $\left(\mathrm{NO}_{2}\right)$ and nitric acid $\left(\mathrm{HNO}_{3}\right)$ on the surface (Zhang et al., 2000; Kline et al., 2004; McNaughton et al., 2009), due to the presence of iron and manganese as catalysts for the formation of these anions, 


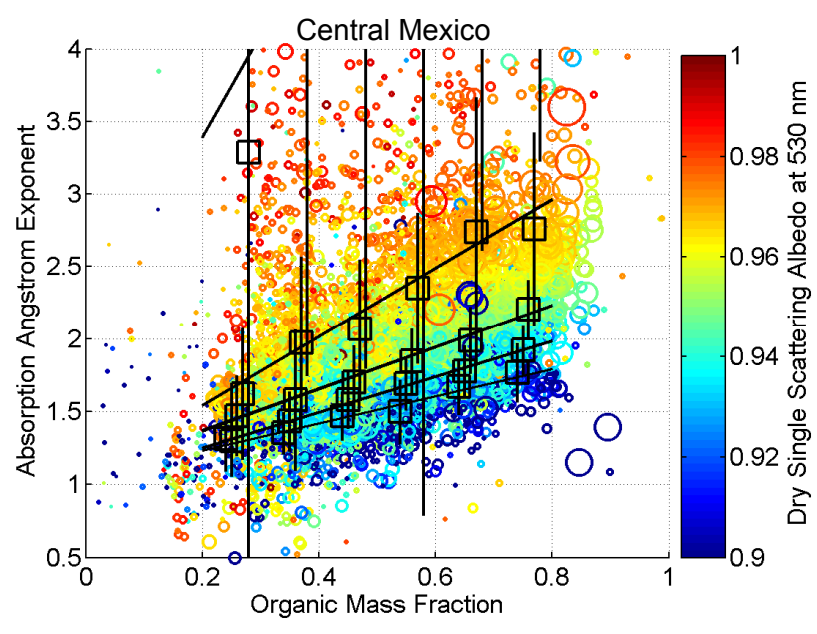

Fig. 7. The Angstrom exponent of absorption measured over Central Mexico, plotted with the AMS organic mass fraction (horizontal axis) and the single scattering albedo at $530 \mathrm{~nm}$ (SSA, color). Marker size is proportional to the dry extinction coefficient $\left(\mathrm{Mm}^{-1}\right)$ at $530 \mathrm{~nm}$. The squares and lines represent the data with the dry extinction exceeding $10 \mathrm{Mm}^{-1}$ for the SSA bins of $0.90-0.92,0.92-0.94,0.94-0.96,0.96-0.98$ and $0.98-$ 1.00 , from left to right. The linear regression to the absorption Angstrom exponent averaged over each $0.1 \mathrm{OMF}$ bin (squares) are $0.9 \times \mathrm{OMF}+1.0,1.2 \times \mathrm{OMF}+1.0,1.4 \times \mathrm{OMF}+1.1,2.4 \times \mathrm{OMF}+1.1$ and $7.1 \times \mathrm{OMF}+2.0$, respectively, with the root mean square of the difference in the Angstrom exponent between the observation and fit being $0.2,0.2,0.3,0.9$ and 5.3, respectively.

fixing with calcium carbonate or reaction of sulfuric and nitric acids. Dust uptake would decrease the anion supply to the non-dust submicron particles. Indeed, the ratio of inorganic mass to excess carbon monoxide concentration was observed to decrease with decreasing Angstrom exponent (Fig. 6b). This could increase the OMF, the relative measure of organic mass in the submicron aerosols. However, this hypothesis about the inorganic compounds and dust does not explain the persistently high submicron organic mass observed under low Angstrom exponent (Fig. 6a).

Unregulated combustion in power plants and other industrial processes may generate significant coarse fly ash and submicron organic material. Some air masses from recent forest fires, marked by enhanced hydrogen cyanide (HCN) relative to carbon monoxide, were associated with supermicron particles, but not all of them were. Aiken et al. (2009) show that dust and biomass burning organic aerosol were high (low) together during the dry (humid) periods inside Mexico City, but that their detailed time-series do not show high correlation, indicating that both emissions are generally increased during dry conditions but are mostly not arising from the same physical processes. Fresh fires represent only a small fraction of the observed data anyway.

\subsubsection{Wavelength dependence of absorption}

Particle absorption may eventually become a tool for identifying some aerosol components by satellite observations. Figure 7 illustrates the relationship among the Angstrom exponent of absorption (AAE) obtained with the 3-wavelength PSAP (plotted over the vertical axis), SSA at $530 \mathrm{~nm}$ (indicated by the marker color) and OMF (horizontal axis) over Central Mexico. For the SSA classes up to 0.98 shown in the figure, the wavelength dependence of absorption decreases with decreasing OMF. If extrapolated to an OMF of 0 , indicative of absence of organic material and, as discussed in Sect. 4.1.1, dust, the AAE would be 1.0-1.1. This observation is consistent with the fact that black carbon absorbs strongly at all wavelengths (Bergstrom et al., 2002; Kirchstetter et al., 2004). It is also evident that the AAE generally increases as OMF or SSA increases. This can be explained by the presence of humic like substances (HULIS) and dust, which are colored (i.e. high AAE), weak (high SSA) absorbers associated with high OMF.

The OMF-SSA-AAE relationships given in Fig. 7 can be used to test model calculations for Central Mexico. Also, high wavelength dependence of absorption in the visible wavelengths may be associated with markedly low SSA near $300 \mathrm{~nm}$ (Barnard et al., 2008; Corr et al., 2009). That may have implications on photolysis rates (of $\mathrm{NO}_{2}$, for example), satellite retrievals of certain trace gases and solar heating rates.

The observed link between optical properties and OMF shown in Fig. 7 also provides a potential new aerosol retrieval technique. Absorption wavelength dependence, together with SSA, can be used to estimate OMF over Central Mexico. Satellite retrievals of these optical parameters would be helpful in cloud-free regions.

\subsection{The relationship between particle hygroscopicity and wavelength dependence of extinction}

The CCN activity may be extrapolated from the humidity response of aerosol size below saturation, as discussed in Sect. 3.2. Consequently, remote sensing of aerosol hygroscopicity would be of value in refining remote sensing of CCN. Unfortunately, only a weak relationship was evident between the TDMA hygroscopicity and the extinction Angstrom exponent (Fig. 3a). For the air masses with high dust mass indicated by the extinction Angstrom exponent smaller than 1.3, the growth factor is near 1 , as expected for its hydrophobic nature.

\section{Conclusions}

Aerosol chemical composition, hygroscopicity, size distributions and multi-wavelength scattering/absorption as well as CCN number concentrations were measured over Central 
Mexico and the US West Coast from aircraft. The relationships between these aerosol properties were examined to assess whether the optical signals that satellites detect can be used to assess aerosol properties including the critical dry diameter. The remote sensing strategy employed in this study is to infer the aerosol chemical composition and to derive the critical dry diameter at $0.2 \%$ supersaturation. This supersaturation is characteristic of extensive low and weakly convective clouds expected to exert a significant climate impact. The findings were:

- The hygroscopicity parameter, $\kappa$, decreases with the organic fraction of submicron non-refractory aerosol mass (OMF), as $\kappa=0.34-0.20 \times \mathrm{OMF}$ and $0.47-0.43 \times \mathrm{OMF}$ over Central Mexico and the US West Coast, respectively, for dry $100 \mathrm{~nm}$ particles. These fits represent the critical dry diameter, which is centered near $100 \mathrm{~nm}$ but varied as $\kappa^{(-1 / 3)}$, within measurement uncertainty $(\sim 20 \%)$. The trends observed during our flights, while largely consistent with previous studies for highly organic particles, extend to smaller organic fractions. That implies a stronger impact of the aerosol chemical composition in determining the $\mathrm{CCN}$ concentration over the regions we investigated compared to fixed-point studies elsewhere. (Sect. 3)

- OMF may be inferred from optical measurements (and possibly remote sensing) to an absolute uncertainty of about 0.3 for Central Mexico's pollution particles. Its anti-correlation with the extinction Angstrom exponent $\left(A_{\text {ext }}\right)$ was observed to be $A_{\text {ext }}=-0.70 \times \mathrm{OMF}+2.0$. The cause for the underlying coexistence of coarse particles and submicron organic mass is not clear. (Sect. 4.1.1)

- The Angstrom exponent of absorption increased with OMF, more rapidly under higher SSA, as expected for the interplay between soot and colored weak absorbers (some organic species and dust); (Sect. 4.1.2).

These observations provide an improved context for understanding the capabilities and limitations for inferring CCN from spectral remote sensing. Moreover, regional characteristics that link spectral properties to aerosol chemical composition suggest potential for tailoring retrievals to specific regions. An example was given for Central Mexico where coarse particle dust revealed in the extinction Angstrom exponent was related to the organic mass fraction of the accumulation mode. Likewise, different couplings between aerosol physicochemistry and optics may exist over other regions. Implementing retrieval schemes for individual regions will probably be essential to the objective of inferring $\mathrm{CCN}$ using remote sensing.

Acknowledgements. We would like to acknowledge support of part of our team through NASA grant NNG04GB39G for this work. YS was partially funded by NASA Earth System Science Graduate Student Fellowship (ESSF/05-0000-0186, 06-ESSF_06R-0111,
07-Earth07R-0100) and NASA Postdoctoral Program, the latter administered by Oak Ridge Associated Universities through a contract with NASA. EJD, PFD, and JLJ were supported by NASA NNG06GB03G and NSF-ATM 0513116 and ATM-0513116, and PFD was recipient of an EPA STAR Fellowship. We thank David Covert (University of Washington) for the 3-wavelength PSAP, and Vaughan Phillips, John Porter, Chris Measures, Barry Huebert (University of Hawaii), Meinrat O. Andreae, Ulrich Pöschl and Sachin Gunthe (Max Planck Institute for Chemistry) and one anonymous referee for their review. We are particularly grateful to support crews of the NCAR C130.

Edited by: S. Madronich

\section{References}

Aiken, A. C., DeCarlo, P. F., and Jimenez, J. L.: Elemental Analysis of Organic Species with Electron Ionization High-Resolution Mass Spectrometry, Anal. Chem., 79, 8350-8358, 2007.

Aiken, A. C., DeCarlo, P. F., Kroll, J. H., Worsnop, D. R., et al.: $\mathrm{O} / \mathrm{C}$ and $\mathrm{OM} / \mathrm{OC}$ Ratios of Primary, Secondary, and Ambient Organic Aerosols with High Resolution Time-of-Flight Aerosol Mass Spectrometry , Environ. Sci. Technol., 42, 4478-4485, 2008.

Aiken, A. C., Salcedo, D., Cubison, M. J., Huffman, J. A., DeCarlo, P. F., Ulbrich, I. M., Docherty, K. S., Sueper, D., Kimmel, J. R., Worsnop, D. R., Trimborn, A., Northway, M., Stone, E. A., Schauer, J. J., Volkamer, R., Fortner, E., de Foy, B., Wang, J., Laskin, A., Shutthanandan, V., Zheng, J., Zhang, R., Gaffney, J., Marley, N. A., Paredes-Miranda, G., Arnott, W. P., Molina, L. T., Sosa, G., and Jimenez, J. L.: Mexico City aerosol analysis during MILAGRO using high resolution aerosol mass spectrometry at the urban supersite (T0) - Part 1: Fine particle composition and organic source apportionment, Atmos. Chem. Phys. Discuss., 9, 8377-8427, 2009, http://www.atmos-chem-phys-discuss.net/9/8377/2009/.

Albrecht, B. A.: Aerosols, cloud microphysics, and fractional cloudiness, Science, 245, 1227-1230, 1989.

Allan, J. D., Coe, H., Bower, K. N., et al.: Technical note: Extraction of chemically resolved mass spectra from Aerodyne aerosol mass spectrometer data, J. Aerosol Sci., 35, 909-922, 2004.

An, W. J., Pathak, R. K., Lee, B. H., and Pandis, S. N.: Aerosol volatility measurement using an improved thermodenuder: Application to secondary organic aerosol, J. Aerosol Sci., 38, 305314, doi:10.1016/j.jaerosci.2006.12.002, 2007.

Anderson, T. L., Covert, D. S., Marshall, S. F., Laucks, M. L., Charlson, R. J., Waggoner, A. P., Ogren, J. A., Caldow, R., Holm, R. L., Quant, F. R., Sem, G. J., Wiedensohler, A., Ahlquist, N. A., and Bates, T. S.: Performance characteristics of a high-sensitivity, three-wavelength, total scatter/backscatter nephelometer, J. Atmos. Ocean. Tech., 13, 967-986, 1996.

Anderson, T. L., Masonis, S. J., Covert, D. S., Ahlquist, N. C., Howell, S. G., Clarke, A. D., and McNaughton, C. S.: Variability of aerosol optical properties derived from in situ aircraft measurements during ACE-Asia, J. Geophys. Res., 108(D23), 8647, doi:10.1029/2002JD003247, 2003.

Anderson, T. L., Wu, Y. H., Chu, D. A., Schmid, B., Redemann, J., and Dubovik, O.: Testing the MODIS satellite retrieval of 
aerosol fine-mode fraction, J. Geophys. Res.-Atmos., 110(D18), D18204, doi:10.1029/2005JD005978, 2005.

Andreae, M. O.: Correlation between cloud condensation nuclei concentration and aerosol optical thickness in remote and polluted regions, Atmos. Chem. Phys., 9, 543-556, 2009,

http://www.atmos-chem-phys.net/9/543/2009/.

Barnard, J. C., Volkamer, R., and Kassianov, E. I.: Estimation of the mass absorption cross section of the organic carbon component of aerosols in the Mexico City Metropolitan Area, Atmos. Chem. Phys., 8, 6665-6679, 2008,

http://www.atmos-chem-phys.net/8/6665/2008/.

Bergstrom, R. W., Russell, P. B., and Hignett, P.: Wavelength dependence of the absorption of black carbon particles: Predictions and results from the TARFOX experiment and implications for the aerosol single scattering albedo, J. Atmos. Sci., 59(3), 567577, 2002.

Bond, T. C., Anderson, T. L., and Campbell, D.: Calibration and intercomparison of filter-based measurements of visible light absorption by aerosols, Aerosol Sci. Tech., 30, 582-600, 1999.

Bougiatioti, A., Fountoukis, C., Kalivitis, N., Pandis, S. N., Nenes, A., and Mihalopoulos, N.: Cloud condensation nuclei measurements in the eastern Mediterranean marine boundary layer: CCN closure and droplet growth kinetics, Atmos. Chem. Phys. Discuss., 9, 10303-10336, 2009,

http://www.atmos-chem-phys-discuss.net/9/10303/2009/.

Canagaratna, M. R., Jayne, J. T., Jimenez, J. L., et al.: Chemical and Microphysical Characterization of Ambient Aerosols with the Aerodyne Aerosol Mass Spectrometer, Mass Spectrom. Rev., 26, 185-222, 2007.

Cappa, C. D., Lack, D. A., Burkholder, J. B., and Ravishankara, A. R.: Bias in filter based aerosol light absorption measurements due to organic aerosol loading: Evidence from laboratory measurements, Aerosol Sci. Tech., 42(12), 1022-1032, 2008.

Clarke, A. D.: A thermo-optic technique for in situ analysis of sizeresolved aerosol physicochemistry, Atmos. Environ., 25A, 635644, 1991.

Clarke, A. D., Varner, J. L., Eisele, F., Mauldin, R. L., Tanner, D., and Litchy, M.: Particle production in the remote marine atmosphere: Cloud outflow and subsidence during ACE 1, J. Geophys. Res., 103(D13), 16397-16409, 1998.

Corr, C. A., Krotkov, N., Madronich, S., Slusser, J. R., Holben, B., Gao, W., Flynn, J., Lefer, B., and Kreidenweis, S. M.: Retrieval of aerosol single scattering albedo at ultraviolet wavelengths at the T1 site during MILAGRO, Atmos. Chem. Phys., 9, 58135827, 2009, http://www.atmos-chem-phys.net/9/5813/2009/.

Cubison, M. J., Ervens, B., Feingold, G., Docherty, K. S., Ulbrich, I. M., Shields, L., Prather, K., Hering, S., and Jimenez, J. L.: The influence of chemical composition and mixing state of Los Angeles urban aerosol on CCN number and cloud properties, Atmos. Chem. Phys., 8, 5649-5667, 2008,

http://www.atmos-chem-phys.net/8/5649/2008/.

DeCarlo, P., Slowik, J. G., Worsnop, D. R., Davidovits, P., and Jimenez, J. L.: Particle Morphology and Density Characterization by Combined Mobility and Aerodynamic Diameter Measurements, Part 1: Theory, Aerosol Sci. Tech., 38, 1185-1205, doi:10.1080/027868290903907, 2004.

DeCarlo, P. F., Dunlea, E. J., Kimmel, J. R., Aiken, A. C., Sueper, D., Crounse, J., Wennberg, P. O., Emmons, L., Shinozuka, Y.,
Clarke, A., Zhou, J., Tomlinson, J., Collins, D. R., Knapp, D., Weinheimer, A. J., Montzka, D. D., Campos, T., and Jimenez, J. L.: Fast airborne aerosol size and chemistry measurements above Mexico City and Central Mexico during the MILAGRO campaign, Atmos. Chem. Phys., 8, 4027-4048, 2008,

http://www.atmos-chem-phys.net/8/4027/2008/.

DeCarlo, P. F., Kimmel, J. R., Trimborn, A., Northway, M. J., Jayne, J. T., Aiken, A. C., Gonin, M., Fuhrer, K., Horvath, T., Docherty, K. S., Worsnop, D. R., and Jimenez, J. L.: Field-Deployable, High-Resolution, Time-of-Flight Aerosol Mass Spectrometer, Anal. Chem., 78(24), 8281-8289, 2006.

Dunlea, E. J., DeCarlo, P. F., Aiken, A. C., Kimmel, J. R., Peltier, R. E., Weber, R. J., Tomlison, J., Collins, D. R., Shinozuka, Y., McNaughton, C. S., Howell, S. G., Clarke, A. D., Emmons, L. K., Apel, E. C., Pfister, G. G., van Donkelaar, A., Martin, R. V., Millet, D. B., Heald, C. L., and Jimenez, J. L.: Evolution of Asian aerosols during transpacific transport in INTEX-B, Atmos. Chem. Phys. Discuss., 8, 15375-15461, 2008,

http://www.atmos-chem-phys-discuss.net/8/15375/2008/.

Dusek, U., Frank, G. P., Hildebrandt, L., et al.: Size Matters More Than Chemistry for Cloud-Nucleating Ability of Aerosol Particles, Science, 312, 1375-1378, 2006.

Ervens, B., Cubison, M., Andrews, E., Feingold, G., Ogren, J. A., Jimenez, J. L., DeCarlo, P., and Nenes, A.: Prediction of $\mathrm{CCN}$ number concentration using Measurements of Aerosol Size Distributions and Composition and Light Scattering Enhancement due to Humidity. J. Geophys. Res.-Atmos., 112, D10S32, doi:10.1029/2006JD007426, 2007.

Facchini, M. C., Mircea, M., Sandro, F., and Charlson, R.J.: Cloud albedo enhancement by surface-active organic solutes in growing droplets, Nature, 401(6750), 257-259, 1999.

Faulhaber, A. E., Thomas, B. M., Jimenez, J. L., et al. : Characterization of a Thermodenuder-Particle Beam Mass Spectrometer System for the Study of Organic Aerosol Volatility and Composition, Atmos. Meas. Tech., 2, 15-31, 2009.

Garland, R. M., Yang, H., Schmid, O., Rose, D., Nowak, A., Achtert, P., Wiedensohler, A., Takegawa, N., Kita, K., Miyazaki, Y., Kondo, Y., Hu, M., Shao, M., Zeng, L. M., Zhang, Y. H., Andreae, M. O., and Pöschl, U.: Aerosol optical properties in a rural environment near the mega-city Guangzhou, China: implications for regional air pollution, radiative forcing and remote sensing, Atmos. Chem. Phys., 8, 5161-5186, 2008, http://www.atmos-chem-phys.net/8/5161/2008/.

Gasparini, R., Li, R., and Collins, D. R.: Integration of size distributions and size-resolved hygroscopicity measured during the Houston Supersite for compositional categorization of the aerosol, Atmos. Environ., 38(20), 3285-3303, 2004.

Gunthe, S. S., King, S. M., Rose, D., Chen, Q., Roldin, P., Farmer, D. K., Jimenez, J. L., Artaxo, P., Andreae, M. O., Martin, S. T., and Pöschl, U.: Cloud condensation nuclei in pristine tropical rainforest air of Amazonia: size-resolved measurements and modeling of atmospheric aerosol composition and CCN activity, Atmos. Chem. Phys. Discuss., 9, 3811-3870, 2009, http://www.atmos-chem-phys-discuss.net/9/3811/2009/.

Hartz, K. E. H., Tischuk, J. E., Chan, M. N., Donahue, C. K. C. N. M., and Pandis, S. N.: Cloud condensation nuclei activation of limited solubility organic aerosol, Atmos. Environ., 40(4), 605617, 2006.

Heald, C. L., Goldstein, A. H., Allan, J. D., Aiken, A. C., Apel, 
E., Atlas, E. L., Baker, A. K., Bates, T. S., Beyersdorf, A. J., Blake, D. R., Campos, T., Coe, H., Crounse, J. D., DeCarlo, P. F., de Gouw, J. A., Dunlea, E. J., Flocke, F. M., Fried, A., Goldan, P., Griffin, R. J., Herndon, S. C., Holloway, J. S., Holzinger, R., Jimenez, J. L., Junkermann, W., Kuster, W. C., Lewis, A. C., Meinardi, S., Millet, D. B., Onasch, T., Polidori, A., Quinn, P. K., Riemer, D. D., Roberts, J. M., Salcedo, D., Sive, B., Swanson, A. L., Talbot, R., Warneke, C., Weber, R. J., Weibring, P., Wennberg, P. O., Worsnop, D. R., Wittig, A. E., Zhang, R., Zheng, J., and Zheng, W.: Total observed organic carbon (TOOC) in the atmosphere: a synthesis of North American observations, Atmos. Chem. Phys., 8, 2007-2025, 2008, http://www.atmos-chem-phys.net/8/2007/2008/.

Heintzenberg, J. and Charlson, R. J.: Design and Applications of the Integrating Nephelometer: A Review, J. Atmos. Ocean. Tech., 13, 987-1000, 1996.

Hoppel, W. A., Frick, G. M., and Fitzgerald, J. W.: Deducing droplet concentration and supersaturation in marine boundary layer clouds from surface aerosol measurements, J. Geophys. Res., 101(D21), 26553-26565, 1996.

Hudson, J. G. and Svensson, G.: Cloud Microphysical Relationships in California Marine Stratus, J. Appl. Meteorol., 34(12), 2655-2666, 1995.

Huffman, J. A., Ziemann, P. J., Jayne, J. T., Worsnop, D. R., and Jimenez, J. L.: Development and Characterization of a Fast-Stepping/Scanning Thermodenuder for ChemicallyResolved Aerosol Volatility Measurements, Aerosol Sci. Tech.., 42, 395-407, 2008.

Jimenez, J. L., Jayne, J. T., Shi, Q., et al.: Ambient Aerosol Sampling with an Aerosol Mass Spectrometer, J. Geophys. Res., 108, 8425, doi:8410.1029/2001JD001213, 2003.

Kahn, R. A., Gaitley, B. J., Martonchik, J. V., et al.: Multiangle Imaging Spectroradiometer (MISR) global aerosol optical depth validation based on 2 years of coincident Aerosol Robotic Network (AERONET) observations, J. Geophys. Res., 110, D10S04, doi:10.1029/2004JD004706, 2005.

Kanakidou, M., Seinfeld, J. H., Pandis, S. N., Barnes, I., Dentener, F. J., Facchini, M. C., Van Dingenen, R., Ervens, B., Nenes, A., Nielsen, C. J., Swietlicki, E., Putaud, J. P., Balkanski, Y., Fuzzi, S., Horth, J., Moortgat, G. K., Winterhalter, R., Myhre, C. E. L., Tsigaridis, K., Vignati, E., Stephanou, E. G., and Wilson, J.: Organic aerosol and global climate modelling: a review, Atmos. Chem. Phys., 5, 1053-1123, 2005,

http://www.atmos-chem-phys.net/5/1053/2005/.

King, S. M., Rosenoern, T., Shilling, J. E., Chen, Q., and Martin, S. T.:, Cloud condensation nucleus activity of secondary organic aerosol particles mixed with sulfate, Geophys. Res. Lett., 34, L24806, doi:10.1029/2007GL030390, 2007.

Kinne, S.: Climatologies of Cloud-related Aerosols: Part 1: Particle number and size, edited by: Heintzenberg, J. and Charlson, R. J.,Cambridge, MA, The MIT Press, ISBN 978-0-262-012874, 37-57, 2009.

Kirchstetter, T. W., Novakov, T., and Hobbs, P. V.: Evidence that the spectral dependence of light absorption by aerosols is affected by organic carbon, J. Geophys. Res., 109, D21208, doi:10.1029/2004JD004999, 2004.

Kline, J., Huebert, B., Howell, S., Blomquist, B., Zhuang, J., Bertram, T., and Carrillo, J.: Aerosol composition and size versus altitude measured from the C-130 during ACE-Asia, J. Geo- phys. Res., 109, D19S08, doi:10.1029/2004JD004540, 2004

Kuwata, M., Kondo, Y., Miyazaki, Y., Komazaki, Y., Kim, J. H., Yum, S. S., Tanimoto, H., and Matsueda, H.: Cloud condensation nuclei activity at Jeju Island, Korea in spring 2005, Atmos. Chem. Phys., 8, 2933-2948, 2008,

http://www.atmos-chem-phys.net/8/2933/2008/.

Lance, S., Medina, J., Smith, J., and Nenes, A.: Mapping the Operation of the DMT Continuous Flow CCN Counter, Aerosol Sci. Tech., 40, 242-254, 2006.

McNaughton, C. S., Clarke, A. D., Howell, S. G., Pinkerton, M., Anderson, B. E., Thornhill, K. L., Winstead, E. L., Hudgins, C. H., Dibb, J. E., Scheuer, E., and Maring, H.: Results from the DC-8 inlet characterization experiment (DICE): Airborne versus surface sampling of mineral dust and sea salt aerosols, Aerosol Sci. Tech., 41(2), 136-159, 2007.

McNaughton, C. S., Clarke, A. D., Kapustin, V., Shinozuka, Y., Howell, S. G., Anderson, B. E., Winstead, E., Dibb, J., Scheuer, E., Cohen, R. C., Wooldridge, P., Perring, A., Huey, L. G., Kim, S., Jimenez, J. L., Dunlea, E. J., DeCarlo, P. F., Wennberg, P. O., Crounse, J. D., Weinheimer, A. J., and Flocke, F.: Observations of heterogeneous reactions between Asian pollution and mineral dust over the Eastern North Pacific during INTEX-B, Atmos. Chem. Phys. Discuss., 9, 8469-8539, 2009.

http://www.atmos-chem-phys-discuss.net/9/8469/2009/.

Molina, L. T., Madronich, S., Gaffney, J., et al.: An Overview of MILAGRO 2006 Campaign: Mexico City Emissions and its Transport and Transformation, submitted to Atmos. Chem. Phys. Discuss., 2009.

Nenes, A., Charlson, R. J., Facchini, M. C., Kulmala, M., Laaksonen, A., and Seinfeld, J. H.: Can chemical effects on cloud droplet number rival the first indirect effect?, Geophys. Res. Lett., 29(17), 1848, doi:10.1029/2002GL015295, 2002.

Petters, M. D. and Kreidenweis, S. M.: A single parameter representation of hygroscopic growth and cloud condensation nucleus activity, Atmos. Chem. Phys., 7, 1961-1971, 2007,

http://www.atmos-chem-phys.net/7/1961/2007/.

Pöschl, U., Rose, D. and Andreae, M. O.: Climatologies of Cloudrelated Aerosols: Part 2: Particle Hygroscopicity and Cloud Condensation Nuclei Activity, edited by: Heintzenberg, J. and Charlson, R. J., Cambridge, MA, The MIT Press, ISBN 978-0-262012874, 2009.

Pruppacher, H. R., and Klett, J. D.: Microphysics of Clouds and Precipitation, 1980.

Quinn, P. K., Bates, T. S., Baynard, T., et al.: Impact of particulate organic matter on the relative humidity dependence of light scattering: A simplified parameterization, Geophys. Res. Lett., 32, L22809, doi:22810.21029/22005GL024322, 2005.

Raymond, T. M. and Pandis, S. N.: Cloud activation of single-component organic aerosol particles, J. Geophys. Res., 107(D24), 4787, doi:10.1029/2002JD002159, 2002.

Remer, L. A., Kaufman, Y. J., Tanré, D., et al.: The MODIS Aerosol Algorithm, Products, and Validation, J. Atmos. Sci., 62, 947973, 2006.

Roberts, G. C. and Nenes, A.: A Continuous-Flow Streamwise Thermal-Gradient CCN Chamber for Atmospheric Measurements, Aerosol Sci. Tech., 39, 206-221, 2005.

Rogers, R. R., Hair, J. W., Hostetler, C. A., Ferrare, R. A., Obland, M. D., Cook, A. L., Harper, D. B., Burton, S. P., Shinozuka, Y., McNaughton, C. S., Clarke, A. D., Redemann, J., Russell, P. B., 
Livingston, J. M., and Kleinman, L. I.: NASA LaRC airborne high spectral resolution lidar aerosol measurements during MILAGRO: observations and validation, Atmos. Chem. Phys., 9, 4811-4826, 2009, http://www.atmos-chem-phys.net/9/4811/2009/.

Rose, D., Gunthe, S. S., Mikhailov, E., Frank, G. P., Dusek, U., Andreae, M. O., and Pöschl, U.: Calibration and measurement uncertainties of a continuous-flow cloud condensation nuclei counter (DMT-CCNC): CCN activation of ammonium sulfate and sodium chloride aerosol particles in theory and experiment, Atmos. Chem. Phys., 8, 1153-1179, 2008a, http://www.atmos-chem-phys.net/8/1153/2008/.

Rose, D., Nowak, A., Achtert, P., Wiedensohler, A., Hu, M., Shao, M., Zhang, Y., Andreae, M. O., and Pöschl, U.: Cloud condensation nuclei in polluted air and biomass burning smoke near the mega-city Guangzhou, China - Part 1: Size-resolved measurements and implications for the modeling of aerosol particle hygroscopicity and CCN activity, Atmos. Chem. Phys. Discuss., 8, 17343-17392, 2008b,

http://www.atmos-chem-phys-discuss.net/8/17343/2008/.

Shinozuka, Y., Clarke, A. D., Howell, S. G., Kapustin, V. N., McNaughton, C. S., Zhou, J., and Anderson, B. E.: Aircraft profiles of aerosol microphysics and optical properties over North America: Aerosol optical depth and its association with $\mathrm{PM}_{2.5}$ and water uptake, J. Geophys. Res., 112, D12S20, doi:10.1029/2006JD007918, 2007.

Shulman, M. L., Jacobson, M. C., Carlson, R. J., Synovec, R. E., and Young, T. E.: Dissolution behavior and surface tension effects of organic compounds in nucleating cloud droplets, Geophys. Res. Lett., 23(3), 277-280, 1996.

Singh, H. B., Brune, W. H., Crawford, J. H., Jacob, D. J., and Russell, P. B.: Overview of the summer 2004 Intercontinental Chemical Transport Experiment - North America (INTEX-A), J. Geophys. Res., 111, D24S01, doi:10.1029/2006JD007905, 2006.

Singh, H. B., Brune, W. H., Crawford, J. H., Flocke, F., and Jacob, D. J.: Chemistry and transport of pollution over the Gulf of Mexico and the Pacific: spring 2006 INTEX-B campaign overview and first results, Atmos. Chem. Phys., 9, 2301-2318, 2009,

http://www.atmos-chem-phys.net/9/2301/2009/.

Sorooshian, A., Murphy, S. M., Hersey, S., Gates, H., Padro, L. T., Nenes, A., Brechtel, F. J., Jonsson, H., Flagan, R. C., and Seinfeld, J. H.: Comprehensive airborne characterization of aerosol from a major bovine source, Atmos. Chem. Phys., 8, 5489-5520, 2008 , http://www.atmos-chem-phys.net/8/5489/2008/.

Stroud, C. A., Nenes, A., Jimenez, J. L., DeCarlo, P. F., Huffman, J. A., Bruintjes, R., Nemitz, E., Delia, A. E., Toohey, D. W., Guenther, A. B., and Nandi, S.: Cloud Activating Properties of Aerosol Observed during CELTIC, J. Atmos. Sci., 64(2), 441459, 2007.

Subramanian, R., Kok, G. L., Baumgardner, D., Clarke, A., Shinozuka, Y., Campos, T. L., Heizer, C. G., and Stephens, B. B.: Black carbon over Mexico: the effect of atmospheric transport on mixing state, mass absorption cross-section, and $\mathrm{BC} / \mathrm{CO}$ ratios, Atmos. Chem. Phys. Discuss., 9, 9081-9115, 2009, http://www.atmos-chem-phys-discuss.net/9/9081/2009/.
Tomlinson, J.M., Li, R., and Collins, D. R.: Physical and chemical properties of the aerosol within the southeastern $\mathrm{Pa}$ cific marine boundary layer, J. Geophys. Res., 112, D12211, doi:10.1029/2006JD007771, 2007.

Twomey, S.: Pollution and the planetary albedo, Atmos. Environ., 8, 1251-1256, 1974.

Ulbrich, I. M., Canagaratna, M. R., Zhang, Q., Worsnop, D. R., and Jimenez, J. L.: Interpretation of organic components from Positive Matrix Factorization of aerosol mass spectrometric data, Atmos. Chem. Phys., 9, 2891-2918, 2009, http://www.atmos-chem-phys.net/9/2891/2009/.

van Donkelaar, A., Martin, R. V., Leaitch, W. R., Macdonald, A. M., Walker, T. W., Streets, D. G., Zhang, Q., Dunlea, E. J., Jimenez, J. L., Dibb, J. E., Huey, L. G., Weber, R., and Andreae, M. O.: Analysis of aircraft and satellite measurements from the Intercontinental Chemical Transport Experiment (INTEX-B) to quantify long-range transport of East Asian sulfur to Canada, Atmos. Chem. Phys., 8, 2999-3014, 2008,

http://www.atmos-chem-phys.net/8/2999/2008/.

Virkkula, A., Ahlquist, N. C., Covert, D. S., Arnott, W. P., Sheridan, P. J., Quinn, P. K., and Coffman, D. J.: Modification, Calibration and a Field Test of an Instrument for Measuring Light Absorption by Particles, Aerosol Sci. Tech., 39(1), 68-83, 2005.

Wang, J., Lee, Y.-N., Daum, P. H., Jayne, J., and Alexander, M. L.: Effects of aerosol organics on cloud condensation nucleus (CCN) concentration and first indirect aerosol effect, Atmos. Chem. Phys., 8, 6325-6339, 2008, http://www.atmos-chem-phys.net/8/6325/2008/.

Yokelson, R. J., Crounse, J. D., DeCarlo, P. F., Karl, T., Urbanski, S., Atlas, E., Campos, T., Shinozuka, Y., Kapustin, V., Clarke, A. D., Weinheimer, A., Knapp, D. J., Montzka, D. D., Holloway, J., Weibring, P., Flocke, F., Zheng, W., Toohey, D., Wennberg, P. O., Wiedinmyer, C., Mauldin, L., Fried, A., Richter, D., Walega, J., Jimenez, J. L., Adachi, K., Buseck, P. R., Hall, S. R., and Shetter, R.: Emissions from biomass burning in the Yucatan, Atmos. Chem. Phys., 9, 5785-5812, 2009, http://www.atmos-chem-phys.net/9/5785/2009/.

Zhang, D., Shi, G.-Y., Iwasaka, Y., and Hu, M.: Mixture of sulfate and nitrate in coastal atmospheric aerosols: individual particle studies in Qingdao $\left(36^{\circ} 04^{\prime} \mathrm{N}, 120^{\circ} 21^{\prime} \mathrm{E}\right)$, China, Atmos. Environ., 34(17), 2669-2679, 2000.

Zhou, J.: Hygroscopic properties of atmospheric aerosol particles in various environments, Ph.D. thesis, Lund University, Lund, Sweden, ISBN 91-7874-120-3, LUTFD2/(TFKF-1025)/1166/(2001), 166 pp., 2001.

Zhou, J., Swietlicki, E., Hansson, H. C., and Artaxo, P.: Submicrometer aerosol particle size distribution and hygroscopic growth measured in the Amazon rain forest during the wet season, J. Geophys. Res., 107(D20), 8055, doi:10.1029/2000JD000203, 2002. 